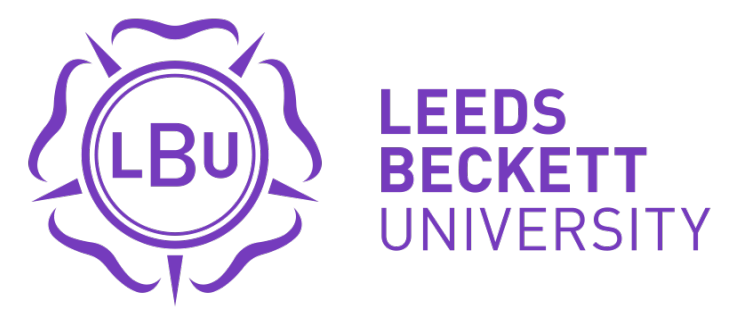

Citation:

Petróczi, A and Dodge, T and Backhouse, SH and Adesanwo, C (2014) Review of the literature on negative health risks based interventions to guide anabolic steroid misuse prevention. Performance Enhancement and Health, 3 (1). 31 - 44. ISSN 2211-2669 DOI: https://doi.org/10.1016/j.peh.2014.08.001

Link to Leeds Beckett Repository record:

https://eprints.leedsbeckett.ac.uk/id/eprint/4/

Document Version:

Article (Accepted Version)

The aim of the Leeds Beckett Repository is to provide open access to our research, as required by funder policies and permitted by publishers and copyright law.

The Leeds Beckett repository holds a wide range of publications, each of which has been checked for copyright and the relevant embargo period has been applied by the Research Services team.

We operate on a standard take-down policy. If you are the author or publisher of an output and you would like it removed from the repository, please contact us and we will investigate on a case-by-case basis.

Each thesis in the repository has been cleared where necessary by the author for third party copyright. If you would like a thesis to be removed from the repository or believe there is an issue with copyright, please contact us on openaccess@leedsbeckett.ac.uk and we will investigate on a case-by-case basis. 
Review of the Literature on Negative Health Risks Based Interventions to Guide Anabolic Steroid Misuse Prevention

\author{
Andrea Petróczi \\ Kingston University \\ Tonya Dodge \\ George Washington University \\ Skidmore College \\ Susan Backhouse \\ Leeds Metropolitan University \\ Christiana Adesanwo \\ Kingston University
}

Author note

Andrea Petróczi, Faculty of Science, Engineering and Computing, Kingston University, Penrhyn Road, Kingston upon Thames, Surrey, KT1 2EE, UK; Tonya Dodge, Skidmore College, 815 North Broadway, Department of Psychology, Saratoga Springs, USA and George Washington University, 2125 G Street NW, Department of Psychology, Washington, DC, USA; Susan Backhouse, Carnegie Research Institute, Leeds Metropolitan University, UK; Jason Mazanov, University of New South Wales-Canberra, School of Business, Canberra BC ACT 
2610, Australia; Christiana Adesanwo, Faculty of Science, Engineering and Computing, Kingston University, Penrhyn Road, Kingston upon Thames, Surrey, KT1 2EE, UK.

Correspondence concerning this article should be addressed to Andrea Petróczi, Faculty of Science, Engineering and Computing, Kingston University, Penrhyn Road, Kingston upon Thames, Surrey, KT1 2EE. A.Petroczi@kingston.ac.uk. 


\title{
Review of the Literature on Negative Health Risks Based Interventions to Guide Anabolic Steroid Misuse Prevention
}

\begin{abstract}
Background. Despite the Internet and the WorldWideWeb providing ready access to information on the risks and health consequences of AS misuse for all ages, AS use remains a public health concern. The aim of this narrative review is to examine the ability of negative health consequences information (NHCI) to prevent adolescent AS misuse in the era of the Internet information revolution.
\end{abstract}

Methods. A search of the literature published between January 2000 and March 2014 was conducted to identify studies that examined the effect of NHCI on AS use and other healthrelated social cognitive constructs and behavior in adolescent samples.

Results. No empirical study was found that specifically investigated the isolated effect of NHCI on AS use. Other health-related intervention studies - involving adolescents - showed that the severity of the consequences tied to social disapproval can be more effective than the severity tied to health consequences. Relevance of NHCI can operate as a moderator or a mediator of the relationship between NHCI and social cognitive constructs and behavior change. Pre-existing knowledge about negative health consequences functions as a mediator of the relationship between NHCI and social cognitive constructs and outcomes.

Conclusion. The best way to understand the effect of NHCI on social cognitive constructs and behavior is to consider it in a larger nomological network that includes perceived severity, vulnerability, relevance and pre-existing knowledge. The review highlights gaps in the literature and suggests directions for future research. Implications for prevention programs are discussed. 
Keywords: anabolic steroids; prevention; health consequences; adolescence; loss-frame; social marketing 


\section{Review of the Literature on Negative Health Risks Based Interventions to Guide Anabolic Steroid Misuse Prevention}

Following psychotropic drugs, performance and appearance enhancing drugs are among the most commonly studied drugs in adolescents (Dodge \& Hoagland, 2011; Kuehn 2009). Some substances - notably growth hormones and anabolic steroids (ASs) - have gained popularity among the general public for their performance and image enhancing properties (Hoffman, Kraemer, Bhasin, Storer, Ratamess, Haff et al., 2009; Kanayama, Hudson, \& Pope, 2008; Kanayama, Hudson, \& Pope, 2010; Perls 2009). ASs are synthetic variants of the naturally occurring male hormone, testosterone (Saudan, Baume, Robinson, Avois, Mangin, \& Saugy, 2006). There are a number of legitimate medical uses for ASs (Basaria, Wahlstrom, \& Dobs, 2001; Creutzberg et al., 2003; Johns, Beddall, \& Corrin, 2005), but the literature shows that some adolescents misuse (non-prescription use without medical supervision) or abuse (excess unsupervised use) ASs to improve athletic performance, physical appearance or size (Cafri, Van der Berg, \& Thompson, 2006; Hoffman, Faigenbaum, Ratamess, Ross, Kang, \& Tenebaum, 2008; Miller, Hoffman, Barnes, Sabo, Melnick, \& Farrell, 2005). Misuse and abuse of ASs is often associated with other substance use (Dodge \& Hoagland, 2011). On average, documented global lifetime prevalence misuse of ASs is 3.3\% with higher prevalence among males (6.4\%) than females (1.6\%) (Sagoe, Molde, Andreassen, Torsheim \& Pallesen, 2014). Among adolescent samples, ASs use is up to $3 \%$ for males and less than $1 \%$ for females (Dodge \& Jaccard, 2006; Dunn \& White, 2011; Lorang, Callahan, Cummins, Achar, \& Brown, 2011; Mattila, Parkkari, Laakso, Pihlajamäki \& Rimpelä, 2010; Nilsson, Baigi, Marklund, \& Fridlund, 2001; Pallesen, Jøsendal, Johnsen, Larsen, \& Molde, 2006; Pope, Kanayama, Athey, Ryan, Hudson \& Baggish, 2013). While some studies have reported AS misuse at higher rates among 
male athletes than male non-athletes (e.g., Dodge \& Jaccard, 2006) other studies have found a general reverse trend. For example, this reverse trend was noted in a German study where nonathletes reported higher rate of AS use than recreational or competitive athletes with the latter group reporting the lowest rates of use (Wanjek, Rosendahl, Strauss \& Gabriel, 2007). In contrast, involvement in sport does not differentiate between female AS users (Elliot, Cheong, Moe \& Goldberg, 2007). Across prevalence studies, sport has not been identified as an unequivocal risk factor for AS use, regardless of gender (Harmer, 2010); making AS use a wider public health problem that stretches beyond the sporting arena (Kanayama et al., 2008).

Research with adults has shown that misuse of ASs can lead to a number of negative health consequences. In brief, these adverse effects include cardiovascular dysfunction (Lane, Grace, Smith, Morris, Cockcroft, Scanlon, et al., 2006; Nottin, Nguyen, Terbah, \& Obert, 2006), liver dysfunction (Kafrouni, Anders, \& Verma, 2007), reproductive difficulties (Knuth, Maniera, \& Nieschlag, 1989) and suicide (Middleman, Faulkner, Woods, Emans, \& DuRant, 1995; Pärssinen, Kujala, Vartiainen, Sarna, \& Seppälä, 2000). A thorough analysis of the adverse effects of AS misuse is presented elsewhere (see Kanayama et al., 2008; Modlinski \& Fields, 2006; Payne, Kotwinski, \& Montgomery, 2004; Pope, Wood, Rogol, Nyberg, Bowers, \& Bhasin, 2014) and these analyses suggest the misuse of ASs by adolescents may pose significant health consequences. Thus, there is general consensus in the medical and professional community that misuse of ASs by adolescents should be prevented (American College of Sports Medicine 2004; American Academy of Pediatrics, 2005). Therefore, it is critical to identify effective approaches to prevent the misuse of AS.

Notably, anti-doping and AS use prevention do not necessarily target the same problem. Doping typically refers to an activity that is regulated by sport governing bodies and defined as 
the use of prohibited substance or methods, including attempt to hide of and assistance in doping use. Anti-doping rules intend to govern the conditions under which sport is played. As such, it involves athletes who engage in competitive sport. On the other hand, AS use is not exclusive to competitive sport. AS use has been evidenced in fitness as well as amateur- and recreational sports, affecting people as young as 12 years old (Dunn \& White, 2011; Kuehn, 2009; Sjöqvist, Garle, \& Rane, 2008; Sagoe, Schou Andreassen \& Pallesen, 2014). The fundamental rationale behind anti-doping in competitive sports, namely promoting universal sport values, equality and fair play, may not apply to fitness and recreational sport. Therefore, AS prevention outside competitive sport may be unaffected by the fair play rationale and thus is likely to be primarily concerned with protecting health. The present review focuses on the latter, centering on health and encompassing all levels and spheres of sport when referring to AS prevention as 'antidoping'. Such phrasing is characteristic of the literature where the term 'doping' is often used to refer exclusively to AS.

\section{Approaches to Prevention}

One seemingly logical approach to prevention is to inform adolescents about, or to emphasize, the potentially hazardous health consequences associated with AS misuse. The premise of this approach is that conveying such information persuades adolescents to refrain from misuse. Although this is appealing at an intuitive level, research in the past has shown the opposite effect (e.g., in Goldberg, Bents, Bosworth, Trevisan and Elliot (1991) specifically, in relation to anabolic steroids). Thus it is important to establish whether there is new evidence that may support such an approach today. Furthermore it is important to identify the intra- inter- and extrapersonal factors can moderate the effect of an information-based intervention that emphasizes the risks and negative health consequences of AS misuse. 
Another approach to prevention draws from the constructivist perspective. According to this perspective, the amount of information is not the only factor that must be considered when designing AS prevention programs. Accepting that information does not equate to knowledge, and that knowledge is not independent of the knower, one must also consider the best way to transform information to knowledge and whether the knowledge can be accessed at critical points in the decision making process. While the constructivist approach to developing AS interventions may seem useful, empirical research is needed to develop evidence based programs that are effective and bring about behavior change.

Although there are no evidence-based AS prevention programs that rely exclusively on a constructivist perspective, there are two prevention programs that incorporate constructivist principles. These programs fell outside the scope of the review but deserve mention here. They are 'The Athletes Training and Learning to Avoid Steroids' ([ATLAS]; Goldberg, Elliot, Clarke, MacKinnon, Zoref, Moe and et al., 1996; Goldberg, MacKinnon, Elliot, Moe, Clarke, \& Cheong, 2000), which focuses on preventing AS use among adolescent males and the 'Athletes Targeting Health Exercise and Nutrition Alternatives' ([ATHENA]; Elliot, Goldberg, Moe, DeFrancesco, Durham, \& Hix-Small, 2004), which focuses on improving body image and preventing drug use among females. Both the ATLAS and ATHENA programs present negative health consequences information [NHCI] about AS use as part of a comprehensive effort aimed at increasing knowledge about how to improve muscle and sport performance (Goldberg \& Elliot, 2005). For example, ATLAS applies sound nutritional principles and weight lifting strategies as safer alternatives to improve muscle mass. The results indicated a significant change in the way adolescents viewed and used ASs and other substances suggesting that AS or doping-based education may generalize to other drug use behavior among adolescent athletes. For a succinct 
chronological account of the development and key outcomes of these programs, readers are referred to Bahrke’s review (2012, pp 1509-1511) and to the original publications for details. Outside the US, AS intervention programs reported after 2000 emerged from Sweden in the early 2000 and, to a limited extent, Iran a decade later. The Swedish AS misuse program for high school students, led by community-based health care workers and youth leaders, lasted for two years and focused on empowering adolescents to make the anti-doping choices via increasing self-confidence, emphasizing behavior over appearance ideals and promoting negative attitudes toward AS instead of using negative health consequences as deterrents. According to the evaluation based on self-reports, the program was considered to be effective in reducing AS misuse and showed increasing attention to AS-related discussions (Nilsson, Allebeck, Marklund, Baigi \& Fridlund, 2004). In a sample of bodybuilders in Iran, one education-based intervention promoting proper nutrition and safe supplement use showed reduced, albeit still very high, selfreported prevalence rates for AS. Specifically, use declined from 50.14\% to 33.44\% (Siabani, Siabani, Rezaei, Abbasi \& Rahimi, 2008). Another intervention study - again involving Iranian bodybuilders - utilised a multidimensional approach involving six 1-hour health education sessions to change AS use. This study showed a reduction in self-reported AS use and intention to use, an increase in knowledge in the experimental group, but recorded no change in subjective norms or perceived control (Jalilian, Allahverdipour, Moeini \& Moghimbeigi, 2011).

Although the evaluations described above have been touted by some as successes, the interpretation of findings have been challenged on multiple levels. In many cases, it is difficult to determine which aspects of the program changed behavior (Hanson, 2009). Evaluations are based around self-reported use and intention to use AS; where the observed reduction in selfreported intention and use can just as much be the desirable consequence of the intervention 
program as the undesirable effect of increased perceived need for impression management. Furthermore, published intervention efforts to date have focused almost exclusively on high school student athletes or bodybuilders. Even if effectiveness is established for the test samples, the transferability of the model to elite sport remains unknown. In addition, Bahrke (2012) notes the possibility of publication bias, namely apart from one notable exception for scare tactics (Goldberg et al., 1991), whereby unsuccessful attempts to AS behavioral change are not submitted for publication. This would lead to an unbalanced account of what works and what does not. Although Goldberg et al. (1991) showed previously that scare tactics alone was ineffective and a balanced educational approach was suggested for adolescents to fully understand the risks associated with AS, this research was conducted before the Internet revolution. Since then, a wide range of information, including those actively promoting AS use, became readily available on the Internet, which makes re-visiting the question timely again.

Therefore the objective of this paper was to review the literature on adolescent health behavior interventions published after the WWW became the key source of health information among adolescents. Specifically, with the view of determining the key characteristics for potential application in AS misuse prevention, this narrative review evaluates research that examines the effect of negative health consequences information (NHCI) on adolescent health behavior change.

\section{Information and Knowledge in the WorldWideWeb era}

Access to information has changed dramatically in the last 15 years with the WorldWideWeb (WWW) increasingly becoming the lead information source for adolescents, including health-related information (Gray, Klein, Noyce, Sesselberg \& Cantrill, 2005; Skinner, Skinner, Biscope, Poland \& Goldberg, 2003). By 2000 - and following the information 
revolution after the commercialization of the Internet in the mid 90s - half of the surveyed adolescents in the western world reported using the WWW for getting health information (Borzekowski \& Rickert, 2001) with no upward trend noted in the proportion of adolescents using the WWW for health information (Ettel III, Nathanson, Ettel, Wilson \& Meola, 2012). Whilst the overall information on AS is fairly balanced with some promoting and others warning against AS use, these information sources typically do not coincide within a single webpage; thus require targeted search. Even so, reviewing thousands of websites, Brennan, Kanayama and Pope (2013) concluded that those promoting the sale and use of AS often explicitly attempt to discredit scientific evidence for harmful effects and question the motivation of the scientific and medical community in warning people against AS. One prominent example of a pro-AS website is www.steroid.com, which boasts over a quarter of a million members (plus open to visitors). This site offers a comprehensive guide for steroid use and purchase; and openly discredits scientific evidence for AS negative health consequences. Research has shown that adolescents use the WWW to fill the gap in their knowledge and whilst they may be concerned about the quality of information available on the WWW, their search skills, health information literacy and ability to evaluate the information source for credibility are limited (Morahan-Martin, 2004; Gray, Klein, Noyce, Sesselberg \& Cantrill, 2005a; 2005b).

Despite the readily available information on AS, concerning misconceptions still persist among the young, typically young males (Christiansen \& Bojsen-Møller, 2012). Consistent accounts of AS use (Pope et al., 2013), polypharmacy (Dodge \& Hoagland, 2011) and poor knowledge (Christiansen \& Bojsen-Møller, 2012), combined with the emerging concern over AS dependency (Kanayama, Brower, Wood, Hudson \& Pope, 2010; Pope et al., 2013) and mounting evidence for the long-term consequences of AS misuse (Lindqvist, Moberg, Eriksson, Ehrnborg, 
Rosén \& Fahlke, 2013), underscore the need for targeted preventive measures. In these preventive efforts, health risks and consequences must be emphasized in such way that it reaches adolescents in a meaningful and credible way (Brashers, Goldsmith \& Hsieh, 2002). The present review catalogues factors that influence the effectiveness of the use of negative health information to prevent adolescent risk behaviors and conclude with recommendation for AS prevention strategies.

\section{Framing Effects}

The use of gain- and loss-frames in health-related messages has been extensively investigated (e.g., Gallagher \& Updegraff, 2012; Latimer, Brawley and Bassett, 2010; O’Keefe \& Jensen, 2008; Van’t Riet, Cox, Cox, Zimet, De Brujin, Van den Putte, et al, 2014). Gainframes highlight the health consequences one would avoid by abstaining from the risk behaviour, whereas loss-frames describe negative health consequences as losses that result from engaging in a risk behavior (e.g., AS use). A meta-analysis summarising 94 empirical studies showed that framing and the function of the behavior change are related (Gallagher \& Updegraff, 2012). In general, gain frames worked better for prevention programmes, whereas no difference was found in encouraging detecting health problem behavior.

A Cochrane review on intervention health message framing (Akl, Oxman, Herrin, Vist, Terrenato, Sperati and et al., 2011) showed that despite people perceived positively framed messages being more effective in comparison to loss-framed messages, there was no actual difference between positive and negative frames in their persuasiveness or effect on actual behavior. Loss-frame messages were more effective than gain-framed messages in goal setting but had no effect on behavior. Furthermore, a great deal of heterogeneity was noted, suggesting an interaction between framing and situations. This conclusion is mirrored in an empirical study 
(van't Riet, Ruiter, Werrij, Candel \& de Vries, 2010) which showed that although loss-frame messages created a more negative affect, the more negative affect resulted in a stronger intention to engage in healthy behavior, suggesting that loss- and gain-framed messages influence behaviour via different mediational pathways. Potentially, loss frames evoke more cognitive processing than gain frames, which in turn translate to a change in beliefs and intentions (Bassett-Gunter, Martin Ginis \& Latimer-Cheung, 2013). This effect could be linked to the valence framing, which posits that negatively framed attitudes are more resilient to change than positively framed opposites (Bizer \& Petty, 2005). Furthermore, Bizer, Larsen and Petty (2011) demonstrated that not only the outcomes of the attitude and behavioural change (e.g. gain vs. loss) but the attitudinal positions can also be framed according to their valence (e.g., in opposition or in support), and in turn this valence framing has an effect on attitude strength and resistance to change. Negatively framed attitude (e.g., opposition to controlling AS use) showed higher levels of attitude certainty and attitude-consistent behavioral intentions compared to the positive frames (e.g., in support for AS control). In relation to doping, Horcajo and De la Vega (2014) noted that the attitude change toward AS use in soccer after receiving persuasive messages for or against legalising doping was the function of the message direction, but the change remained persistent one week after the exposure only when high level of elaboration was required from the participants as part of the intervention. This observation, coupled with the fact that negating negatively framed positions requires more cognitive effort than arguing against pro-attitudes could be successfully exploited in AS prevention. Anti-AS messages that induce people to think about AS in terms of opposition based on the negative consequences (as oppose to thinking about avoiding AS to maintain good health and psychological well-being) and prompt to think about themselves as anti-doping supporters are likely to have stronger and longer 
lasting effect than those framed in positive valence terms. Therefore it is timely to re-visit the question whether emphasizing the negative health consequences of AS is a facile way to create strong anti-AS attitude in adolescents.

\section{Negative Health Consequences and Fear Appeals}

In general, NHCI conveys medical consequences associated with risk taking behaviors. For example, anti-smoking campaigns might show the lungs of a person suffering smoking related chronic obstructive pulmonary disease. Presenting NHCI this way is one component of public health fear appeals approaches.

Fear appeals are defined as attempts at persuasion that include some combination of fear, perceived efficacy, and perceived threat where fear is described as a negative emotion associated with arousal (Witte \& Allen, 2000). Two distinct aspects of perceived efficacy are: i) selfefficacy, the belief in personal capability to successfully engage in some recommended action and ii) response-efficacy, the belief that the recommended action will be effective at preventing the threat. As with efficacy, there are two components of perceived threat: (a) susceptibility, perceived likelihood engaging in the risk behavior leads to the threat and (b) severity, the belief about how adverse the consequences will be.

In the literature NHCI is typically varied as a function of outcome severity and susceptibility, where an audience is provided with information about how severe the negative health consequences will be in conjunction with how likely the audience is to experience the consequences. In this way existing research (Witte \& Allen, 2000) implies that NHCI can serve as one component of fear appeals because it can be varied with respect to fear, perceived threat and perceived efficacy.

\section{Persuasion and Fear Appeals}


Several reviews of the literature have examined the utility of fear appeals in persuading the target audience to avoid risk taking or to engage in protective behaviors. For example, Witte and Allen's (2000) meta-analysis found that stronger fear appeals led to greater feelings of threat and were more persuasive than weak fear appeals. That is, strong fear appeals led to more adaptive behaviors aimed at avoiding the fear than did weak fear appeals, but the effect size was small. de Hoog, Stroebe and de Wit’s (2007) meta-analysis corroborates this finding, showing feelings of vulnerability influenced intentions and behavior change in the direction of the recommendation provided.

However, Witte and Allen (2000) showed strong fear appeals could lead to more defensive processing where an individual may discount or ignore the message. Similarly, de Hoog and colleagues (2007) reported that vulnerability sometimes led to minimization or discounting of the message. This minimization, in turn, could result in sustained intent and engagement in risk behavior.

The meta-analyses point to a complex relationship between fear appeals and information processing, intentions and behavior. In sum, stronger perceptions of fear within a message result in stronger attitude, intention and behavior change when coupled with high efficacy (Witte \& Allen, 2000). It appears that stronger fear appeals can lead to greater changes in intentions and behavior than weaker fear appeals, providing for the possibility that defensive processing may reduce the effectiveness of the appeal on behavior change. However, this observation does not factor in the messenger, the method of delivery or the age specific characteristics of the audience. These factors are addressed later independently.

\section{Present Study}


Although the meta-analyses provide a framework for understanding how NHCI might affect adolescent AS misuse, the reviews are limited in several ways. One limitation is that a majority of the studies in the meta-analyses focused on adults, making it difficult to ascertain how use of NHCI affects adolescents. Adolescence is a transition from reliance on adult supervision (as a child) to adult status with self-responsibility. This transition is influenced by dramatic changes in both body and mind, coupled with cognitive, affective and behavioral systems of the still developing brain following different trajectories (Steinberg, 2005). The ability to anticipate the outcome of present actions is lower in childhood and adolescence relative to adulthood owing to the stage-specific developmental changes in the brain (Crone \& van der Molen, 2004). Part of this is demonstrated in the characteristic adolescent focus on the 'now', making it hard for adolescents to think about being old, let alone in ill health (Crone \& van der Molen, 2004; Steinberg, 2005). The difference in how the brain processes information is demonstrated in studies showing that adolescents (aged 10-15 years) feel more vulnerable to a variety of risks than emerging or young adults (aged 20-30 years) (Millstein \& Halpern-Felsher, 2002), yet are more likely than older individuals to take risks (Steinberg, 2007). As a result of developmental changes in the brain, the adolescent response to NHCI or fear appeals may differ from that of adults.

A second limitation is that the meta-analyses included a wide range of risk behaviors. Some were specifically related to risk-taking, like alcohol use (Kleinot \& Rogers, 1982), drug use (Smart \& Fejer, 1974) and sexually transmitted infections (Struckman-Johnson, 1994), but some included behaviors unrelated to risk-taking like earthquake preparedness (Duval \& Mulilis, 1999) and water conservation (Kantola, Syrne, \& Nesdale, 1983). Thus, the fear in some studies 
was unrelated to health behaviors. Furthermore, there has been no focused analysis of how NHCI, specifically, affects adolescent risk-taking behavior.

In response to these limitations, the present paper reviews existing literature on use of NHCI to prevent adolescent risk behaviors. The primary objective is to identify whether presenting NHCI is a viable approach for preventing AS misuse among adolescents.

\section{Methods}

\section{Search Strategies}

A thorough search of recent literature was conducted. Studies published between January 2000 and March 2014 written in English and involving adolescent samples (ages 12-22 years) were identified. Various combinations of the following search terms included, but were not limited to, prevention, fear appeal, alcohol, health messages, health warnings, drug(s), steroid use, drug use, loss frame, health behavior, threat appeals, fear messages, fear arousal, primary prevention, preventive education, education, anabolic steroids, doping, substance use, health, intervention. Terms were searched using the databases Embase, Medline, PsychARTICLES, PsycINFO, PubMed, Scopus, Sociological Abstracts, ScienceDirect and Web of Science.

\section{Selection of Studies and Inclusion Criteria}

Two steps were used to identify articles for inclusion. The first step was to identify potentially relevant articles based on titles and abstracts. At the second step, investigators reviewed candidate studies against the following criteria: (a) included an adolescent sample, (b) described the NHCI used and (c) reported analyses of the relationship between NHCI and some outcome variable. The studies included in the review are shown in Table 1. Studies that failed to describe NHCI and/or described NHCI, but failed to test how it affected social cognitive constructs or behavior were excluded. 
[INSERT TABLE 1 HERE]

\section{Results}

Despite a sustained interest in the non-medical use of AS, no studies were published that examined the impact of NHCI on the prevention of adolescent AS misuse between the study period of 2000 and 2013. The review therefore encompasses studies with adolescent samples that examine the effects of NHCI in a variety of contexts including, healthy lifestyle and health promotion, nutritional habits, obesity, drug use, smoking, alcohol consumption, road safety (e.g., speeding, drinking and driving), condom use and HIV testing, breast cancer, skin cancer, inhalant use and fictitious disease. Outcome variables in the studies included a variety of social cognitive constructs, like information processing and attitudes, as well as intentions and behavior. NHCI presented to adolescents varied along the intra- and interpersonal dimensions as well as situational (i.e., relevance of the threat and perceived severity) and contextual (i.e., characteristics of the intervention and/or message) factors.

Inter-Individual Differences Age. A meta-analysis showed young people were more affected by social than physical consequences shown over multiple-exposures than singleexposures, whereas older audiences were more affected by physical than social consequences independent of the number of exposures (Keller \& Lehman, 2008). This is consistent with work in brain development processing during adolescence and into adulthood which shows adolescents possess a limited ability to process complex and conflicting information on a cognitive level compared to adults (Steinberg, 2005). Age difference was also noted in participants' focus on the audiovisual message. In comparison with older adults, young adults 
exhibited more focus on the video presenting NHIC and risk about skin cancer but employed less protective methods against sun exposure (Isaacowitz \& Choi, 2012).

Self-efficacy. In addition to relevance, self-efficacy is another factor to consider when examining the effect of NHCI on social cognitive constructs and behavior. Self-efficacy is the belief in the personal capability to successfully complete a task (Bandura, 1986). In the health context, efficacy refers to an adolescent's belief that s/he has the capacity to take preventative action to avoid some health threat. There is evidence to suggest that efficacy serves as a moderator of the relationship between NHCI and social cognitive outcomes and behavior. For example, Schneider and colleagues (2009) presented undergraduates with NHCI about a fictitious disease. Those with high efficacy elaborated more on the message (when given the time), reported higher intentions to get tested for the disease, and were more likely to take information about testing than undergraduates with low efficacy. In conjunction with the level of worry, using high-efficacy - low-worry information was more effective than the high-worry and low efficacy message content.

Body consciousness. In a study comparing message framing, body consciousness interacted with the message frame (Hevey, Pertl, Thomas, Maher, Craig \& Ni Chuinneagain, 2010). Despite targeting the same desirable behavior (sunscreen use), participants with a high level of body consciousness responded more strongly to positive frames than to loss frames. Open-mindedness. Self-affirmation exercises, focusing on positive aspects of the self, could have a positive effect on people's openness to intervention messages if administered prior to intervention. Indeed, such effects were demonstrated for general anti-doping intervention (Barkoukis, Lazuras \& Harris, 2014), where participants were asked to complete a 10-question written task prior to exposure to the anti-doping message. This self-affirmation manipulation, 
developed by Reed and Aspinwall (1998), asked athletes to explicitly reflect on general situations where they were kind, caring, compassionate and good. With regard to its effect with NHCI specifically, the literature is limited. Using emotional alcohol warning posters among college students, it was found that self-affirmation exercises positively moderated the effect of on intention to reduce alcohol consumption and reduced actual consumption. Further, this effect was stronger for high behavioral risk students (Scott, Brown, Phair, Westland \& Schüz, 2013). In a study, where self-affirmation was combined with gain- vs. loss-framed antismoking video messages Zhao and Nan (2010) found interaction with framing. Specifically, the self-affirmation effect was favorable with loss-frames but produced inverse effect (i.e., increased anger and negative thoughts toward the messages) when the messages were gain-framed. On the contrary, no effect from self-affirmation was found for encouraging fruit and vegetable consumption when combined with a threatening text outlining the health consequences of insufficient fruit and vegetable intake (Pietersma \& Dijkstra, 2011). Taken together, these studies suggest that selfaffirmation may play a role when the behavior change aim is to curb or reduce an unwanted behavior as opposed to promote a desirable behavior. This proposition is supported by a qualitative-creative study in which young adolescents designed posters for promoting delayed onset of sexual activity and used a mix of loss-framed posters with unwanted pregnancy and HIV risk; and gain-framed posters with academic achievements as a potential positive outcome from delayed sexual initiation (Camenga, Hieftje, Fiellin, Edelman, Rosenthal \& Duncan (2014).Situational Factors

Relevance refers to how applicable an adolescent believes NHCI is to him or her. Closely related to relevance is involvement. Involvement refers to how central or important the adolescent feels the issue is. In general, an issue that is relevant will increase involvement and, 
likewise, an issue in which one is involved is one that is relevant to the adolescent. Keller and Lehman's (2008) meta-analysis found non-central features of a communication were more persuasive when audiences were not involved in the issue compared to when they were involved. Although all audiences reacted to moderately fearful messages, when an audience was uninvolved in the issue, trivial or non-central characteristics of the message were important in determining the level of persuasion. In contrast, when audiences were highly involved in the issue, the non-central or trivial characteristics of the message had no effect on persuasion.

Relevance and involvement as moderators. Some research has shown personal relevance of the message moderates the impact of NHCI on message processing (Cho \& Salmon 2006; Crano, Siegel, Alvaro, \& Patel, 2007; Rothman, Bartel, Wlaschin, \& Salovey, 2008). For example, users of inhalant drugs rated an anti-inhalant message stressing the physical harms of use less favorably than a message that stressed social harms (Crano et al., 2007). There were no differences between message favorability among the non-users. Freeman, Hennessy and Murzullo (2001) found smoking status, smoking identity and future smoking plans moderated the evaluation of an anti-smoking segment such that smokers, those with a strong smoking identity and those with future plans to smoke engaged in more defensive processing than those for whom the message was less relevant. In the context of skin cancer prevention, Cho and Salmon (2006) found college undergraduates in the pre-contemplation stage (i.e., no intention to stop risky behavior) reported less favorable attitudes toward recommendations provided in a message, reported weaker intentions, and at a 4-week follow-up engaged in fewer protective behaviors than those in the contemplation/preparation phase (i.e., considering or plan to start preventative behavior). Together these studies imply the effect of NHCI on social cognitive constructs is moderated by relevance. More specifically, the effect of NHCI may be weaker 
when the message is relevant to the target audience than when the message is irrelevant by virtue of defensive processing. Research has also reported that message involvement may moderate the effect of gain and loss frames on prevention and detection behaviors (Rothman, et al., 2006). The nature of these relationships is described below in the section on framing.

Relevance and involvement as mediators. While relevance appeared in some cases to serve as a moderator of the relationship between NHCI and social cognitive constructs and behavior change in adolescent samples, other research suggests it functions as a mediator. For example, involvement and relevance mediated the effectiveness, as well as the process, between the type of message (e.g. gain or loss framing, fear arousal, comparative alternatives, perceived vulnerability, health, legal and social consequences) and outcome (Cauberghe, De Pelsmacker, Janssens, \& Dens, 2009; Rothman, et al., 2006). In one such study, Cauberghe and colleagues (2009) examined the effect of an anti-speeding public service announcement (PSA) on attitudes and intentions to speed in the future. Results showed that fear of negative health consequences (resulting from a car accident), perceived threat, and efficacy influenced message involvement which, in turn, influenced anti-speeding attitudes and intention to accept the message. Thus, the effect of fear, threat, and efficacy was mediated by involvement such that high levels of fear, threat, and efficacy led to high involvement, which in turn, was responsible for more negative attitudes toward speeding and lower intentions to speed.

\section{Contextual Factors}

Threat severity refers to how significant (i.e., bad or harmful) an adolescent perceives the negative health consequences to be. Perceived vulnerability refers to how susceptible an adolescent feels to the negative health consequences associated with risk behaviors. When 
adolescents are presented with NHCI, their beliefs that the consequences could in fact happen to them personally reflect perceptions of vulnerability.

Threat severity. de Hoog and colleagues (2007) suggest that greater threat severity is more effective at changing behavior than weaker threat severity, although there is evidence indicating this is not always the case. Henley and Donovan (2003) reported high severity had no more of an effect on adolescents' social cognitive constructs than low severity health consequences. In this study, high severity was reflected by premature death as a consequence of smoking while low severity was reflected by non-death consequences or threats. Results showed death and non-death smoking threats were equally effective at changing smoking attitudes and immediate intentions (Henley \& Donovan, 2003), but the study was an observational study without experimental manipulation. Contrary to the common belief that adolescents feel they are immortal, death prospects were noted to be effective but not invariably the most effective threats. There is also evidence suggesting adolescents may be responsive to a different type of severity information: severity of social disapproval. Advertisements eliciting risk perceptions of severe social disapproval were found to be more effective at increasing adolescents' nonsmoking intentions than other antismoking message themes which were cosmetic (e.g. bad breath). However, this outcome could equally be explained by the fact that owing to the developmental characteristics, adolescents process the current and present easier (e.g., short term cosmetic effect from smoking) than they do the potential long-term effects (e.g., serious health consequences of smoking). Thus, among adolescents, fear appeals focusing on long term consequences can be counterproductive and lead to unintentional deleterious effects (Hastings, Stead, \& Webb, 2004; Witte \& Allen, 2000). As Pechmann, Zhao, Goldberg and Reibling 
(2003) assert, "in the context of low perceived vulnerability, stressing health risks could increase smoking's symbolic value as risk seeking, rebellious and thus attractive behavior” (p. 11).

Perceived vulnerability. Perceived vulnerability plays an important role in the acceptance of fear-arousing communications whereby the stronger the effects of vulnerability on fear, negative affect and intentions, the more behavior change one can expect (de Hoog, et al., 2007). However, adolescents often do not perceive themselves to be particularly vulnerable to health risks. For example, Pechmann and colleagues (2003) found that few adolescents felt vulnerable to health risks, which undermined the effectiveness of the health severity messages. Indeed, higher perceived health risk severity was associated with stronger intentions to smoke among youths who felt immune to health risks (Pechmann et al., 2003).

\section{Message and Medium}

While most of the above sections deal with the content of the message (e.g., threat, severity, efficacy), message characteristics are also reported in the studies included in this review.

Message content. Glock and Krolak-Schwerdt (2013) compared alcoholic beverage labels containing NHCI to information provision focused on negating positive outcome expectations from drinking alcohol. They found that the latter proved to be more promising for changing patterns of alcohol consumption in a desirable direction than health-focused messages.

Message framing. Some important characteristics include whether the NHCI was presented using a loss-frame or a gain-frame, along with the overall mode of delivery. To recap, loss-frames describe negative health consequences as losses that result from engaging in a risk behavior (e.g., AS use) and gain-frames highlight the health consequences one would avoid by abstaining from the risk behavior. A meta-analysis found gain-framed messages emphasizing 
the benefits of compliance with the recommendation to avoid negative health consequences were more influential for sustaining health-promoting behaviors than loss-framed messages emphasizing the negative outcomes associated with failure to follow the recommendation (O’Keefe \& Jensen, 2008). However, the effect size was small.

In another study adolescents responded more favorably toward a loss-framed message that depicted tooth decay as a consequence of smoking, than a gain-framed message (Goodall \& Appiah, 2008). Adolescents predicted the loss-framed message would lead to lower intentions to smoke in the future and that the loss-framed message more accurately reflected the consequences of smoking than the gain-framed message. In this study, message frame failed to have a statistically significant effect on adolescents' self-reported intentions to smoke in the future, suggesting what adolescents perceive as the best approach to risk reduction, may not be the most effective. In smoking cessation, adolescents found gain-frame video message more innovative and preferable, yet more positive attitudes toward quitting resulted from the loss-framed version emphasizing the costs and not the benefits from quitting smoking (Latimer, Krishnan-Sarin, Cavallo, Duhig, Salovey \& O'Malley, 2012). While the above studies imply the framing of NHCI may have a direct effect on social cognitions and behavior, Rothman and colleagues (2006) argue framing effects may be moderated by involvement or relevance. That is, the strength of the effect of a gain- or loss-framed message on social cognitions and behavior may depend on the target’s level of involvement. Specifically, Rothman et al. (2006) suggest the influence of gain-frames on the adoption of prevention behaviors may be stronger when involvement is high compared to when involvement is low. Similarly, the influence of lossframes on the adoption of detection behaviors is stronger when involvement is high compared to when involvement is low. 
Interaction effects between message framing and other factors. The effect of message framing cannot be interpreted in isolation. A study focusing on sun protection showed that the relative effect of message framing is better understood in the context of perceived risk level and perceived effectiveness of the protection (Hwang, Cho, Sands \& Jeong, 2012). Similar results were reported from a study looking at the complexity of the way frame and threat may interact (Zimmerman, Cupp, Abadi, Donohew, Gray, Gordon \& Grossl, 2014). Using public announcements on marijuana as intervention messages, this study confirmed that loss-frames were more effective with high perceived risk, but strong effects were also noted with low perceived risk. The overall result suggested that loss-frames bring about greater effects on perceived threat but, conversely, gain-frames are better able to reduce positive attitudes toward marijuana use.

Message format and mode of delivery. There are numerous options for the mode of delivering NHCI. In the studies reviewed, modes of delivery included pictorial warnings, text only and video. While it seems the delivery mode of NHCI may be important to consider, only one study compared different modes of delivery against one another. Terblanche-Smit and Terblanche (2010) presented NHCI that varied with respect to how scary the messages were. The information was presented either via television or print. Results showed a positive relationship between how scary the message was and the amount of fear experienced by adolescents. However, this finding only held true for those who received the information via the television, suggesting that television might be more effective at evoking fear than print. The study failed to examine how modes of delivering NHCI affect other social cognitive constructs (e.g., attitudes) and behavior. Adolescents (age range of 13-18 years) perceived graphical 
tobacco warning labels more effective than the textual format (Vardavas, Connolly, Karamanolis \& Kafatos, 2009).

Interaction between framing and other conditions. An interaction effect between framing and delivery format emerged for smoking warning. More specifically, loss-framing was more effective when delivered alongside graphic warning labels. However, when textual warning labels were considered, framing made no difference (Zhao, Nan, Yang \& Iles, 2014).

Source credibility. In addition to the message content and delivery, characteristics of the source (e.g., credibility) can also influence the effectiveness of the message. Generally, credibility refers to how trustworthy and likable an adolescent perceives the source to be. A source that is trustworthy is one that appears to have nothing to gain by presentation of the message.

Adolescent search patterns of health information provide insight into the perceived credibility of different sources. Ackard and Neumark-Sztainer (2001) found that the majority of adolescents would seek health information from their mother first, followed by a medical practitioner (physician or nurse) and peers. By comparison, a sample of Israeli students derived most information about smoking from school-based programs, followed by parents and physicians (Sperber, Peleg, Friger, \& Shvartzman, 2001). Together these studies imply that adolescents typically view parents and physicians as credible sources of information, but which source is most credible depends on the topic in question.

It is important to note that these studies were conducted 'pre- internet', so it is unclear how credibly adolescents perceive internet based health information. Gray, Klein, Noyce, Sesselberg and Cantrill (2005) found the perceived credibility of internet sources was influenced by perceived variation in expertise and trustworthiness. That is, adolescents were critical 
consumers of information from the Internet. While critical judgments were made by assessing perceived expertise and trustworthiness of the web site, it was not possible to develop general rules regarding how adolescents made such decisions. Further research is therefore warranted.

\section{Effect of Knowledge}

Knowledge as a moderator. In a study with undergraduate students, those with high perceived knowledge reported greater intentions to take preventative action when the negative health consequences message was weak compared to when the message was strong (Nabi, Roskos-Ewoldsen, \& Carpentier, 2008). In contrast, individuals with low perceived knowledge reported greater intentions to take preventative action when the negative health consequences message was strong compared to when the message weak. Thus, the effect of the severity of a negative health consequences message may depend on the knowledge level of the audience.

Knowledge as a mediator. Presenting NHCI may lead to improvements in knowledge, but such increases have led to surprising outcomes. For example, Mazanov and Byrne (2007) showed that Australian adolescents' knowledge of the negative health consequences of smoking had no relationship with onset, maintenance or cessation. If this result generalizes to other substance use, it suggests knowledge of negative health consequences has little impact on prevention. Unexpectedly, adolescent smokers knew more about the negative health consequences of smoking than non-smokers. This is consistent with work by Sperber and colleagues (2001), where despite 97\% of the Israeli students surveyed knowing active smoking was bad for them, smoking rates rose from $2.6 \%$ to $14.2 \%$ over the three years of the study. In the doping context, Yesalis and Bahrke (2000) caution an increase in knowledge about ASs may increase adolescent curiosity and subsequent use. 
There is also evidence to suggest a lack of knowledge about AS places adolescents at risk for use. For example, research on adolescent ergogenic supplement use has shown that lack of knowledge makes adolescents more susceptible to misinformation from peers, trainers and marketers (Bell, Dorsch, McCreary, \& Hovey, 2004). Therefore, failing to provide knowledge about negative health consequences, results in adolescents with knowledge deficits that can make them more susceptible to misinformation than adolescents with accurate knowledge about negative health consequences. Laure and Binsinger (2005) argue that susceptibility to dope from ‘enticers’ (e.g., people in the adolescent’s social network who promote doping) is based on incomplete information that emphasizes the positive outcomes of doping. That is, enticers go about creating an impression that doping is free of negative health consequences by deliberately omitting information.

While deficits in actual knowledge about negative health consequences can make adolescents susceptible to misinformation (Bell et al., 2004; Laure \& Binsinger, 2005), work by Goldberg and colleagues (2003) demonstrate that the more negatively an adolescent perceives the consequences of AS misuse, the less likely they are to use. Together these studies imply that prevention efforts should do more than alter adolescents’ perceptions about negative health consequences associated with AS misuse, as such perceptions may or may not be based upon accurate knowledge (Bell et al., 2004; Laure \& Binsinger, 2005).

Knowledge delivered through passive communication. Tobler and colleagues (2000) described the limited effects of prevention programs that introduce knowledge about drugs using non-interactive and lecture-orientated approaches. In their meta-analysis of 207 universal schoolbased drug-prevention programs, the mean effect size of programs that emphasized drug knowledge using these one-way approaches demonstrated small effects (which remained small 
even when the analysis was restricted to high quality interventions). This limited effect appears to have been heeded in the prevention field because only $9 \%$ of the designs examined were knowledge-focused. This contrasts with the social influence approaches, which made up $40 \%$ of the drug prevention programs (Tobler et al., 2000).

\section{Discussion}

Between January 2000 and March 2014, no studies were published examining the specific effect of NHCI on use of ASs or other social cognitive outcomes related to AS use. The emerging themes identified in this review map neatly onto a holistic social marketing framework that attempts to synthesize the diverse and often controversial findings of social marketing experiments (Helmig \& Thaler, 2010).

In sum, the literature that examines the relationship between NHCI and social cognitive and behavioral outcomes with adolescent samples indicates a complex relationship between the content of information, characteristics of the message, and the source. This review suggests the best way to understand the effect of NHCI on social cognitive constructs and behavior is to consider it in a larger nomological network that includes constructs like perceived severity vulnerability, relevance, self-efficacy, and source credibility. Additional variables that emerged as important to consider were pre-existing knowledge, characteristics of the message and interindividual differences. This finding reiterates the conclusions of an earlier review, commissioned by the World Anti-Doping Agency (WADA) on lessons learned from established prevention fields (Backhouse, McKenna, \& Patterson, 2009). Finally, caution about the amount of NHCI is also warranted. Providing too much information could backfire through psychological mechanisms such as cognitive overload, information salience and availability, and perceived credibility (Peters, Klein, Kaufman, Meilleur \& Dixon, 2013). 


\section{Implications for the Design of Steroid Prevention Programs}

To create more harmony between the anti-doping message and the individual and temporal stages of a doping act, Johnson, Sacks \& Edmonds (2010) propagate targeted, individual intervention strategies that follow the transtheoretical model and apply the principles of motivational interviewing. Whilst such an approach is appealing it may be cost- prohibitive for global interventions. However, the theoretical underpinnings of Johnson and colleagues's proposition (2010) map onto the interactional-transformational models of (Leventhal \& Schmitz, 2006) and its doping interpretation (Petroczi \& Aidman, 2008). Changing outcome expectancies regarding AS offers a feasible avenue for AS-prevention and intervention targeting transition stages from one class of substances to another (Petroczi, 2014).

Age specific limitations. Adolescents have difficulties navigating complex socialemotional situations (Steinberg, 2005) and this evidence should be considered when planning AS misuse prevention. Owing to developmental changes in the brain, adolescents have temporary limited executive functioning and are yet to acquire the full decision-making capacity that enables full comprehension and anticipation of future consequences to present actions (Crone \& van der Molen, 2004; Luna, Padmanabhan, \& O’Hearn, 2010; Yurgelun, 2007).

Adolescents, therefore, tend to reduce complex situations to simplistic right or wrong frameworks and respond emotionally rather than analytically. Consequently, AS prevention campaigns targeting adolescents should recognize that interventions relying on changing knowledge, beliefs, or attitudes, or the way adolescents think about risk, may be ineffective (Steinberg, 2007). Unique characteristics of this developmental period, such as a dualistic right or wrong framework, heightened emotions, sensation seeking and the risky decision context should be explicitly accounted for in AS prevention activity design. 
Knowledge. The effect of knowledge in the prevention of AS misuse is complex. Knowledge about AS misuse should be conveyed to adolescents through the development of their ability to refute misinformation and recognize the omission of important information from others attempting to persuade the adolescent to misuse AS. One such strategy is the constructivist approach advocated by Hanson (2009), which aims to reduce susceptibility of adolescents to misinformation by overcoming deficits in knowledge. However, there is a chance that providing accurate knowledge may have no effect on risk behavior or may even lead to increases in such activities.

Message delivery. Who delivers the message appears to have a significant effect on adolescent processing of NHCI. For example, adolescents’ experimentation with substances like AS may be discouraged if preventative messages are provided and reinforced by trusted sources such as parents or physicians rather than, say, high profile athletes (Peterson, 2010).

Evidence suggests that lecture style presentations have little effect, and serve only to create disengagement with the health issues (Backhouse et al., 2009). Therefore, AS prevention programs should be activity oriented and the importance of participant interaction for achieving intervention effectiveness continues to be reinforced (Backhouse et al., 2009). Equally, PSAs about negative health consequences raise population level awareness and may even have some short-term effects (e.g. anti-speeding campaigns), but rarely equate to systemic long-term reductions in behavior unless sustained over a chronic period (e.g. Australia’s anti-smoking campaign "Every cigarette is doing you damage”). Such campaigns run the risk of desensitizing the population to an issue.

Role of the Internet in message delivery. To date, on-line interventions are being explored more fully as an individualized method of reducing drinking behavior and eating 
disorders among adolescents. Results of such studies suggest that those who complete brief or protracted interventions in this format show desired behaviors (Tobler et al., 2000), but whether this is sustained has yet to be established. However, Internet delivery of health information is evidently becoming more prominent as a portal for adolescents to build health literacy in an anonymous way, circumventing anxieties around sensitive topics such as acne or warts (Gray et al., 2005). Thus, this mode of delivery should be considered when designing AS education programs.

Work in this area typically looks at the effect of web-based information dissemination on health behavior. For example, when a sample of Dutch adolescents were allowed to search a website anonymously, adolescents searched within the site for advice on how to improve their health with regard to issues like nutrition, smoking and alcohol consumption (Crutzen, de Nooijer, Candel, \& de Vries, 2008). Studies have also shown that alcohol prevention programs delivered via the web can lead to greater awareness about alcohol misuse (Hustad, Barnett, Borsari, \& Jackson, 2010). Finally, a computer-delivered parent-involvement study to prevent substance use among adolescent girls showed after two years, the program appeared to prevent substance use problems within the cohort from getting worse (Schinke, Fang, \& Cole, 2009).

Content delivered through these programs varied considerably (i.e., some included health promotion information, some included facts about outcomes associated with alcohol use), which makes it difficult to know whether the mode of delivery or type of content led to improvements. Nonetheless, these studies suggest that it is worthwhile to examine AS prevention programs delivered on-line. Furthermore, exposure to credible on-line information sources has shown to have a positive effect on adolescents health literacy (Ghaddar, Valerio, Garcia \& Hansen, 2012), which would enable young people finding accurate information on AS risks outside the 
intervention program period and equip them with transferable skills for seeking other healthrelated information.

\section{Gaps in the Doping Literature}

Results of this narrative review highlight the complexities of the effects of NHCI by identifying several possible mediators and moderators. Additionally, this review revealed several gaps in the literature on doping, and particularly targeted AS use prevention aimed at adolescents. These gaps include the use of social marketing, the role of institutions, reasons for use and cultural consequences, and are described below.

The role of social marketing in AS prevention. Empirical studies on the effectiveness of systematic use of marketing communication strategies to change undesirable behavior are largely missing from the AS prevention literature specifically, and the anti-doping literature generally. Although a conceptual, system level framework for applying social marketing to general anti-doping has been put forward (O'Reilly \& Madill, 2007; O’Reilly, Pegoraro, \& Madill, n.d.), translation of these strategies to practical prevention initiatives is yet to be done. Future studies should consider the full range of consequences from social marketing communication, including inadvertently raising awareness about undesirable substances (James, Naughton \& Petróczi, 2010), as well as the default conscious and voluntary nature of behavioral change (Nosek \& Riskind, 2012) and law of regulating acceptable marketing methods (Donovan, 2011). Based on the importance of social approval among adolescents (Pechmann, et al., 2003), one area where social marketing may be successfully employed is in correcting the likely misperceptions about the prevalence of AS use among peers (Sanders, Stogner, Seibert \& Miller, 2014). 
The role of institutions in prevention. Notably absent from the literature is research that examines how adolescents perceive information from institutions with vested interests in AS prevention like the WADA, National Anti-Doping Organizations or public health advocates. For example, there is no indication how adolescents weight information from official sources relative to those of family or friends. Harmer's (2010) review suggests that non-elite adolescent athletes may weigh official information as largely irrelevant. For example, education around compliance with the World Anti-Doping Code would be irrelevant for low level or non-athletes (Lucidi, Grano, Leone, Lombardo, \& Pesce, 2004). The credibility of an anti-AS or anti-doping message may be undermined if the adolescents feel the information conveyed by the Code does not apply to them personally. Even elite athletes may be skeptical of such messages, in part, because adolescents are more likely to trust sources they believe are acting in their best interests, such as parents, physicians, coaches or administrators. It is possible that institutions with vested interests in anti-doping or AS prevention are viewed as less credible than other sources of information, such as physicians.

Relationship between reasons to use and intervention messages. Experimental work aiming to ascertain the effectiveness of various intervention strategies manipulating framing and message content seldom took into consideration reasons why the adolescent was engaging in the risk behavior (or failing to engage in prevention) in the first place. This has two implications. There is a notable absence of research developing interventions that use positive frames to offer acceptable alternatives. Research among adult gym patrons, suggests that such an intervention can change beliefs regarding performance enhancing substances (James et al., 2010). The other, equally important outcome is the potential mismatch between reasons one is engaging in the behavior and the content of the message itself, whereby the message can easily be discarded if it 
fails to address the reasons behind the action (Petróczi, Mazanov, \& Naughton, 2011). For example, if a young person is motivated to misuse ASs to enhance appearance or athletic performance outside competitive sport, a message that focuses on playing by the rules and promoting fair play is unlikely to be relevant to him or her. Consequently, this message is likely to be ignored.

Cultural consequences. Despite the globally harmonized nature of anti-doping and the impact on doping-related cognitive processes, motivation and behavior (Petroczi, 2014), there is a notable vacuum in the literature on cultural effects. Extrapolating the findings from research integrating culture into social cognition research (e.g., Han \& Jo, 2012; Oyserman \& Lee, 2008; Uskul \& Oyserman, 2010), it is highly likely that anti-doping education could be more effective if the key anti-doping messages at the national level are matched to the cultural frame of the given country; and reinforced with salient situational cues. Taking the cultural context into consideration in devising and evaluating anti-AS campaigns or investigating the effect of fit or misfit between pervasive cultural characteristics and anti-doping education is strongly recommended.

\section{Limitations}

Although the present review provides information that should be considered when designing AS prevention programs that include NHCI, there are several limitations that deserve mention. The present review defined adolescent samples as ages 12 years to college aged. A majority of the studies included samples at the upper end of this range, making it difficult to draw firm conclusions regarding the effectiveness of NHCI among younger adolescents. The reviewed studies presented NHCI to participants under experimental conditions. It remains unknown whether adolescents would actively seek negative health information if the choice is 
given, or how they would process conflicting information (i.e., both positive and negative consequences) from multiple sources. Finally, the focus of the review was the effect of NHCI on social cognitive constructs and behaviors. This reflects a small portion of possible approaches to building prevention programs and omits approaches like comprehensive education programs (e.g., those which include both perceived benefits and costs associated with ASs) and programs based on social influence approaches (e.g., correcting norms). Despite these limitations, this review provides a number of suggestions for AS prevention programming and future research that are detailed in the section below.

\section{Conclusion}

Contrary to the previous conclusion made about fear appeals almost a quarter of a century ago stating that fear appeal is not working in AS prevention, negative health information consequences in fact may do have a place in current anti-doping communication. However, the message based on negative consequences must be theory-based, targeted, relevant and credible. Multilevel studies provided overwhelming evidence that message framing cannot be fully understood without considering the contextual contingencies. The interaction between message framing and individual dispositions, open-mindedness and perceptions should be further explored. Given the global nature of anti-doping efforts, consideration should be given to enhancing the desirable effect of AS prevention by matching the negative health consequences to prevailing cultural frames. 


\section{References}

Ackard, D., \& Neumark-Sztainer, D. (2001). Health care information sources for adolescents: Age and gender differences on use, concerns, and needs. Journal of Adolescent Health, 29, 170-176.

Akl, E.A., Oxman, A.D., Herrin, J., Vist, G.E., Terrenato, I., Sperati, F., Costiniuk, C., Blank, D., Schünemann, H. (2011). Framing of health information messages. Cochrane Database of Systematic Reviews, 12, CD006777.

American College of Sports Medicine (2004). Position statement. Senate Hearing on the Abuse of ASs and Their Precursors by Adolescent Athletes. Retrieved from: http://www.acsm.org/Content/ContentFolders/Publications/PositionStands/Position_Stateme nt_Senate_Hearing_on_the_Abuse_of_Anabolic_Steroids_and_Their_Precursors_by_Adole sc.htm.

American Academy of Pediatrics (2005). Use of performance-enhancing substances. Pediatrics, 115, 1103-1106.

Backhouse, S. H., McKenna, J., \& Patterson, L. (2009). Prevention through Education: A Review of Current International Social Science Literature, A focus on the prevention of bullying, tobacco, alcohol and social drug use in children, adolescents and young adults. Montreal, Canada: World Anti-Doping Agency.

Bahrke, M. S. (2012). Performance-enhancing substance misuse in sport: risk factors and considerations for success and failure in intervention programs. Substance Use \& Misuse, 47(13-14), 1505-1516.

Bandura, A. (1986). Social foundations of thought and action. Englewood Cliffs, NJ: Prentice Hall. 
Barkoukis, V., Lazuras, L., \& Harris, P. R. (2014). The effects of self-affirmation manipulation on decision making about doping use in elite athletes. Psychology of Sport and Exercise, doi:10.1016/j.psychsport.2014.02.003.

Basaria, S., Wahlstrom, J.T., \& Dobs, A. S. (2001). Anabolic androgenic steroid therapy in the treatment of chronic diseases. Journal of Clinical Endocrinology and Metabolism, 86(11), 5108-5117.

Bassett-Gunter, R. L., Martin Ginis, K. A., \& Latimer-Cheung, A. E. (2013). Do you want the good news or the bad news? Gain-versus loss-framed messages following health risk information: the effects on leisure time physical activity beliefs and cognitions. Health Psychology, 32(12), 1188-1198.

Bell, A., Dorsch, K. D., McCreary, D. R., \& Hovey, R. (2004). A look at nutritional supplement use in adolescents. Journal of Adolescent Health, 34(6), 508-516.

Bizer, G. Y., Larsen, J. T., \& Petty, R. E. (2011). Exploring the valence-framing effect: negative framing enhances attitude strength. Political Psychology, 32(1), 59-80.

Bizer, G. Y., \& Petty, R. E. (2005). How we conceptualize our attitudes matters: The effects of valence framing on the resistance of political attitudes. Political Psychology, 26(4), 553-568.

Borzekowski, D. L., \& Rickert, V. I. (2001). Adolescent cybersurfing for health information: a new resource that crosses barriers. Archives of Pediatrics \& Adolescent Medicine, 155(7), 813-817.

Brashers, D. E., Goldsmith, D. J., \& Hsieh, E. (2002). Information seeking and avoiding in health contexts. Human Communication Research, 28(2), 258-271.

Brennan, B. P., Kanayama, G., \& Pope, H. G. (2013). Performance-Enhancing Drugs on the Web: A Growing Public-Health Issue. The American Journal on Addictions, 22(2), 158-161. 
Byrne, D. \& Mazanov, J. (2008). Personality, stress and the determination of smoking behavior in adolescents. In G. Boyle, G. Matthews, D. Saklofske (eds). Handbook of personality theory and testing (pp 698-719). London: Sage..

Cafri, G., Van der Berg, P., \& Thompson, J. K. (2006). Pursuit of muscularity in adolescent boys: relations among biopsychosocial variables and clinical outcomes. Journal of Clinical Child and Adolescent Psychology, 35(2), 283-291.

Camenga, D. R., Hieftje, K. D., Fiellin, L. E., Edelman, E. J., Rosenthal, M. S., \& Duncan, L. R. (2014). The use of message framing to promote sexual risk reduction in young adolescents: a pilot exploratory study. Health Education Research, doi: 10.1093/her/cyt156.

Cauberghe, V., De Pelsmacker, P., Janssens, W., \& Dens, N. (2009). Fear, threat and efficacy in threat appeals: Message involvement as a key mediator to message acceptance. Accident Analysis and Prevention, 41(2), 276-285.

Cho, H., \& Salmon, C.T. (2006). Fear appeals for individuals in different stages of change: Intended and unintended effects and implication on public health campaigns. Health Communication, 20(1), 91-99.

Christiansen, A.V., \& Bojsen-Møller, J. (2012). “Will steroids kill me if I use them once?” A qualitative analysis of inquiries submitted to the Danish anti-doping authorities. Performance Enhancement \& Health, 1, 39-47.

Crano, W.D., Siegel, J. T., Alvaro, E. M., \& Patel, N. M. (2007). Overcoming adolescents' resistance to anti-inhalant appeals. Psychology of Addictive Behaviors, 21(4), 516-524.

Crone, E.A. \& van der Molen, M.W. (2004). Developmental changes in real life decision making: performance on a gambling task previously shown to depend on the ventromedial prefrontal cortex. Developmental Neuropsychology, 5(3), 251-279. 
Creutzberg, E.C., Wouters, E. F. M., Mostert, R., Pluymers, R. J., \& Schols, A. M. W. J. (2003).

A role for anabolic steroids in the rehabilitation of patients with COPD? A double-blind, placebo-controlled, randomized trial. Chest, 124(5), 1733-1742.

Crutzen, R., de Nooijer, J., Candel, M. J. J. M., \& de Vries, N. K., (2008). Adolescents who intend to change multiple health behaviors choose greater exposure to an Internet-delivered intervention. Journal of Health Psychology, 13(7), 906-911.

de Hoog, N., Stroebe, W., \& de Wit, J.B.F. (2007). The Impact of Vulnerability to and Severity of a Health Risk on Processing and Acceptance of Fear-Arousing Communications: A Meta-Analysis. Review of General Psychology, 11(3), 258-285.

Dodge, T., \& Hoagland, M.F. (2011). The use of anabolic androgenic steroids and polypharmacy: A review of the literature, Drug and Alcohol Dependence, 114(2-3), 100-109. Dodge, T.L., \& Jaccard, J. (2006). The effect of high school sports participation on the use of performance-enhancing substances in young adulthood. Journal of Adolescent Health, 39(3), 367-373.

Donovan, R. (2011). Social marketing's mythunderstandings. Journal of Social Marketing, 1(1), 8-16.

Dunn, M., \& White, V. (2011). The epidemiology of anabolic-androgenic steroid use among Australian secondary school students. Journal of Science and Medicine in Sport, 14(1), 1014.

Duval, T.S., \& Mulilis, J-P. (1999). A person-relative-to-event (PrE) approach to negative threat appeals and earthquake preparedness. Journal of Applied Social Psychology, 29(3), 495-516. 
Elliot, D. L., Cheong, J., Moe, E. L., \& Goldberg, L. (2007). Cross-sectional study of female students reporting anabolic steroid use. Archives of Pediatrics \& Adolescent Medicine, 161(6), 572-577.

Elliot, D.L., Goldberg, L., Moe, E. L., DeFrancesco, C. A., Durham, M. B., \& Hix-Small, H. (2004). Preventing substance use and disordered eating: Initial outcomes of the ATHENA program. Archives of Pediatric and Adolescent Medicine, 158(11), 1043-1049.

Ettel III, G., Nathanson, I., Ettel, D., Wilson, C, \& Meola, P. (2012). How do adolescents access health information? And do they ask their physicians?. The Permanente Journal, 16(1), 3538.

Freeman, M A., Hennessy, E.V., \& Marzullo, D.M. (2001). Defensive evaluation of antismoking messages among college-age smokers: The role of possible selves. Health Psychology, 20(6), 424-433.

Gallagher, K. M., \& Updegraff, J. A. (2012). Health message framing effects on attitudes, intentions, and behavior: a meta-analytic review. Annals of Behavioral Medicine, 43(1), 101-116.

Ghaddar, S. F., Valerio, M. A., Garcia, C. M., \& Hansen, L. (2012). Adolescent health literacy: the importance of credible sources for online health information. Journal of School Health, 82(1), 28-36.

Glock, S., \& Krolak-Schwerdt, S. (2013). Changing outcome expectancies, drinking intentions, and implicit attitudes toward alcohol: a comparison of positive expectancy-related and health-related alcohol warning labels. Applied Psychology: Health and Well-Being, 5(3), 332-347. 
Goldberg, L., Bents, R., Bosworth, E., Trevisan, L., \& Elliot, D.L. (1991). Anabolic steroids education and adolescents: do scare tactics work? Pediatrics, 87(3), 283-286.

Goldberg, L., Elliot, D. L., Clarke, G. N., MacKinnon, D. P., Zoref, L., Moe, E., Green, C., \& Wolf, S. L. (1996). The Adolescents Training and Learning to Avoid Steroids (ATLAS) prevention program: background and results of a model intervention. Archives of Pediatrics \& Adolescent Medicine, 150(7), 713-721.

Goldberg, L., \& Elliot, D. L. (2005). Preventing substance use among high school athletes: The ATLAS and ATHENA programs. Journal of Applied School Psychology, 21(2), 63-87.

Goldberg, L., MacKinnon, D., P., Elliot, D. L., Moe, E. L., Clarke, G., \& Cheong, J. (2000). The adolescent training and learning to avoid steroids program: preventing drug use and promoting health behaviors. Archives of Pediatric and Adolescent Medicine, 154(4), 332338.

Goodall, C., \& Appiah, O. (2008). Adolescents’ Perceptions of Canadian Cigarette Package Warning Labels: Investigating the Effects of Message Framing. Health Communication, 23 (2), 117-127.

Gray, N.J., Klein, J., D., Noyce, P. R., Sesselberg, T. S., \& Cantrill, J. A. (2005a). Health information-seeking behavior in adolescence: The place of the internet. Social Science and Medicine, 60(7), 1467-1478.

Gray, N. J., Klein, J. D., Noyce, P. R., Sesselberg, T. S., \& Cantrill, J. A. (2005b). The Internet: a window on adolescent health literacy. Journal of Adolescent Health, 37(3), 243e1 $243 e 7$. 
Han, K. H., \& Jo, S. (2012). Does culture matter?: a cross-national investigation of women's responses to cancer prevention campaigns. Health Care for Women International, 33(1), $75-94$.

Hanson, J. (2009). Equipping athletes to make informed decisions about performance-enhancing drug use: A constructivist perspective from educational psychology. Sport in Society, 12(3), $394-410$

Harmer, P.A. (2010). Anabolic-androgenic steroid use among young male and female athletes: Is the game to blame? British Journal of Sports Medicine, 44(1), 26-31.

Hastings, G., Stead, M., \& Webb, J. (2004). Fear appeals in social marketing: strategic and ethical reasons for concern. Psychology and Marketing, 21(11), 961-986.

Helmig, B. and Thaler, J. (2010) On the Effectiveness of social marketing - what do we really know? Journal of Nonprofit \& Public Sector Marketing, 22(4), 264- 287.

Henley, N. \& Donovan, R.J. (2003). Young people’s response to death threat appeals: do they really feel immortal? Health education research, 18(1), 1-14.

Hoffman, J. R., Faigenbaum, A. D., Ratamess, N. A D., Ross, R., Kang, J., \& Tenebaum, G. (2008). Nutritional supplementation and anabolic steroid use in adolescents. Medicine and Science in Sport and Exercise, 40(1), 15-24.

Hoffman, J.R., Kraemer, W. J., Bhasin, S., Storer, T., Ratamess, N. A., Haff, G., Willoughby, D. S...Rogol, A. D. (2009). Position Stand on Androgen and Human Growth Hormone Use. Journal of Strength \& Conditioning Research, 23(5), S1-S59.

Horcajo, J., \& De la Vega, R. (2014). Changing doping-related attitudes in soccer players: How can we get stable and persistent changes? European Journal of Sport Science, doi:10.1080/17461391.2014.905988. 
Hustad, J. T. P., Barnett, N. P., Borsari, B., \& Jackson, K. M. (2010). Web-based alcohol prevention for incoming college students: A randomised controlled trial. Addictive Behaviors, 35(3), 183-189.

Hwang, Y., Cho, H., Sands, L., \& Jeong, S. H. (2012). Effects of gain-and loss-framed messages on the sun safety behavior of adolescents: The moderating role of risk perceptions. Journal of Health Psychology, 17(6), 929-940.

Isaacowitz, D. M., \& Choi, Y. (2012). Looking, feeling, and doing: are there age differences in attention, mood and behavioral responses to skin cancer information?. Health Psychology, 31(5), 650-659.

Jalilian, F., Allahverdipour, H., Moeini, B., \& Moghimbeigi, A. (2011). Effectiveness of anabolic steroid preventative intervention among gym users: Applying theory of planned behavior. Health Promotion Perspectives, 1(1), 32-40.

James, R., Naughton, D.P., \& Petróczi, A. (2010). Promoting functional foods as acceptable alternatives to doping: potential for information-based social marketing approach. Journal of International Society for Sports Nutrition, 37, 7.

Johns, K.K.J., Beddall, M.J., \& Corrin, R.C. (2005). Anabolic steroids for the treatment of weight loss in HIV-infected individuals. Cochrane Database of Systematic Reviews, 4, CD005483. DOI: 10.1002/14651858.Cd005483.

Johnson, M. C., Sacks, D. N., \& Edmonds, W. A. (2010). Counseling athletes who use performance-enhancing drugs: a new conceptual framework linked to clinical practice. Journal of Social, Behavioral, and Health Sciences, 4(1), 1-29. 
Kafrouni, M.I., Anders, R.A., \& Verma, S. (2007). Hepatotoxicity associated with dietary supplements containing anabolic steroids. Clinical Gastroenterology and Hepatology, 5(7), 809-812.

Kantola, S.J., Syrne, G.J., \& Nesdale, A.R. (1983). The effects of appraised severity and efficacy in promoting water conservation: An information analysis. Journal of Applied Social Psychology, 13(2), 164-182.

Kanayama, G., Brower, K. J., Wood, R. I., Hudson, J. I., \& Pope, H. G. (2010). Treatment of anabolic-androgenic steroid dependence: Emerging evidence and its implications. Drug and Alcohol Dependence, 109(1), 6-13.

Kanayama, G., Hudson, J.I, \& Pope, H.G. (2008). Long-term psychiatric and medical consequences of anabolic-androgenic steroid abuse: A looming public health concern? Drug and Alcohol Dependence, 98(1-2), 1-12.

Kanayama, G., Hudson, J.I, \& Pope, H.G. (2010). Illicit anabolic-androgenic steroid use. Hormones and Behavior, 58(1), 111-121.

Keller, P.A., \& Lehmann, D.R. (2008). Designing effective health communications: A metaanalysis. Journal of Public Policy \& Marketing, 27(2), 1-26.

Kuehn, B.M. (2009). Teen steroid, supplement use targeted: officials look to prevention and better oversight. JAMA, 302(21), 2301-2303.

Kleinot, M.C. \& Rogers, R.W. (1982). Identifying effective components of alcohol misuse prevention programs. Journal of Studies on Alcohol, 43(7), 802-811.

Knuth, U.A., Maniera, H., \& Nieschlag, E. (1989). Anabolic Steroids and semen parameters in bodybuilders. Fertility and Sterility, 52, 1041-1047. 
Lane, H.A., Grace, F., Smith, J. C., Morris, K., Cockcroft, J., Scanlon, M. F., \& Davies, J. S. (2006). Impaired vasoreactivity in bodybuilders using adrogenic anabolic steroids. European Journal of Clinical Investigation, 36(7), 483-488.

Latimer, A. E., Brawley, L. R., \& Bassett, R. L. (2010). A systematic review of three approaches for constructing physical activity messages: what messages work and what improvements are needed?. International Journal of Behavioral Nutrition and Physical Activity, 7, 36.

Laure, P., \& Binsinger, C. (2005). Adolescent athletes and the demand and supply of drugs to improve their performance. Journal of Sports Science and Medicine, 4, 272-277.

Latimer, A. E., Krishnan-Sarin, S., Cavallo, D. A., Duhig, A., Salovey, P., \& O'Malley, S. A. (2012). Targeted smoking cessation messages for adolescents. Journal of Adolescent Health, 50(1), 47-53.

Lindqvist, A. S., Moberg, T., Eriksson, B. O., Ehrnborg, C., Rosén, T., \& Fahlke, C. (2013). A retrospective 30-year follow-up study of former Swedish-elite male athletes in power sports with a past anabolic androgenic steroids use: a focus on mental health. British Journal of Sports Medicine, doi:10.1136/bjsports-2012-091340.

Lorang, M., Callahan, B., Cummins, K. M., Achar, S., \& Brown, S. A. (2011). Anabolic androgenic steroid use in teens: prevalence, demographics, and perception of effects. Journal of Child \& Adolescent Substance Abuse, 20(4), 358-369.

Lucidi, F., Grano, C., Leone, L., Lombardo, C., \& Pesce, C. (2004). Determinants of the intention to due doping substances: An empirical contribution in a sample of Italian adolescents. International Journal of Sports Psychology, 35(2), 133-148.

Luna, B., Padmanabhan, A., \& O’Hearn, K. (2010). What has fMRI told us about the development of cognitive control through adolescence? Brain Cognition, 72(1), 101-113. 
Mattila, V. M., Parkkari, J., Laakso, L., Pihlajamäki, H., \& Rimpelä, A. (2010). Use of dietary supplements and anabolic-androgenic steroids among Finnish adolescents in 1991-2005. The European Journal of Public Health, 20(3), 306-311.

Mazanov, J., \& Byrne, D.G. (2007). Changes in adolescent smoking behavior and knowledge of health consequence of smoking. Australian Journal of Psychology, 59(3), 176-180.

Middleman, A.B., Faulkner, A. H., Woods, E. R., Emans, S. J., \& DuRant, R. H. (1995). Highrisk behaviors among high school students in Massachusetts who use anabolic steroids. Pediatrics, 96(2), 268-272.

Miller, K.E., Hoffman, J. H., Barnes, G. M., Sabo, D., Melnick, M. J., \& Farrell, M. P. (2005). Adolescent anabolic steroid use, gender, physical activity and other problem behaviors. Substance Use \& Misuse, 40(11), 1637-1657.

Millstein, S.G., \& Halpern-Felsher, B.L. (2002). Judgments about risk and perceived invulnerability in adolescents and young adults. Journal of Research on Adolescence, 12(4), $399-422$.

Morahan-Martin, J. M. (2004). How internet users find, evaluate, and use online health information: a cross-cultural review. CyberPsychology \& Behavior, 7(5), 497-510.

Modlinski, R., \& Fields, K.B. (2006). The effect of anabolic steroids on the gastrointestinal system, kidneys and adrenal glands. Current Sports Medicine Reports, 5(2), 104-109.

Nabi, R.L., Roskos-Ewoldsen, D., \& Carpentier, F.D. (2008). Subjective knowledge and fear appeal effectiveness: Implications for message design. Health Communication, 23(2), 191201. 
Nilsson, S., Baigi, A., Marklund, B., \& Fridlund, B. (2001). The prevalence of use of androgenic anabolic steroids by adolescents in a county of Sweden. European Journal of Public Health, 11(2), 195-197.

Nilsson, S., Allebeck, P., Marklund, B., Baigi, A., \& Fridlund, B. (2004). Evaluation of a health promotion programme to prevent the misuse of androgenic anabolic steroids among Swedish adolescents. Health Promotion International, 19(1), 61-67.

Nosek, B.A., \& Riskind, R.G. (2012). Policy implications of implicit social cognition. Social Issues and Policy Review, 6, 112-145.

Nottin, S., Nguyen, L. D., Terbah, M., \& Obert, P. (2006). Cardiovascular effects of androgenic anabolic steroids in male body builders determined by tissue Doppler imaging. The American Journal of Cardiology, 97(6), 912-915.

O’Keefe, D.J., \& Jensen, J.D. (2008). Do loss-framed persuasive messages engender greater message processing than do gain-framed messages? A meta-analytic review. Communication Studies, 59(1), 51-67.

Oyserman, D., Lee, S.W.S. (2008). Does culture influence what and how we think? Effects of priming individualism and collectivism. Psychological Bulletin, 134, 311-342.

Pallesen, S., Jøsendal, O., Johnsen, B. H., Larsen S., \& Molde, H. (2006). Anabolic steroid use in high school students. Substance Use \& Misuse, 41(13), 1705-1717.

Pärssinen, M., Kujala, U., Vartiainen, E., Sarna, S., \& Seppälä (2000). Increased premature mortality of competitive powerlifters suspected to have used anabolic agents. International Journal of Sports Medicine, 21(3), 225-227.

Payne, J.R., Kotwinski, P.J., \& Montgomery, H.E. (2004). Cardiac effects of anabolic steroids. Heart, 90(5), 473-475. 
Pechmann,C., Zhao, G., Goldberg, M. E., \& Reibling, E. T. (2003). What to convey in antismoking advertisements for adolescents: The use of protection motivation theory to identify effective messages themes. Journal of Marketing, 67, 1-18.

Perls, T.P. (2009). Growth hormone and anabolic steroids: athletes are the tip of the iceberg. Drug Testing and Analysis, 1(9-10), 419-425.

Peters, E., Klein, W., Kaufman, A., Meilleur, L., \& Dixon, A. (2013). More is not always better: intuitions about effective public policy can lead to unintended consequences. Social Issues and Policy Review, 7(1), 114-148.

Peterson, T.S. (2010). Good athlete-bad athlete? On the "role model argument” for banning performance-enhancing drugs. Sports, Ethics and Philosophy, 4(3), 332-340.

Petróczi, A., \& Aidman, E. (2008). Psychological drivers in doping: the life-cycle model of performance enhancement. Substance Abuse Treatment, Prevention, and Policy, 3(1), 7.

Petróczi, A., Mazanov, J., \& Naughton, D.P. (2011). Inside athletes’ minds: Preliminary results from a pilot study on mental representation of doping and implications for anti-doping Substance Abuse, Treatment Prevention and Policy, 6, 10.

Petróczi, A. (2014). The doping mindset - Part I. Implications of the Functional Use Theory on mental representations of doping. Performance Enhancement and Health, doi: 10.1016/j.peh.2014.06.001.

Pietersma, S., \& Dijkstra, A. (2011). Do behavioral health intentions engender health behavior change? A study on the moderating role of self-affirmation on actual fruit intake versus vegetable intake. British Journal of Health Psychology, 16(4), 815-827. 
Pope Jr, H. G., Wood, R., Rogol, A., Nyberg, F., Bowers, L., \& Bhasin, S. (2014). Adverse health consequences of performance-enhancing drugs: An Endocrine Society scientific statement. Endocrine Reviews, 35, 341-375.

Pope, H. G., Kanayama, G., Athey, A., Ryan, E., Hudson, J. I., \& Baggish, A. (2013). The lifetime prevalence of anabolic-androgenic steroid use and dependence in Americans: Current best estimates. The American Journal on Addictions, doi: 10.1111/j.15210391.2013.12118.x.

O'Reilly, N., \& Madill, J. (2007). The World Anti-Doping Agency: the role of social marketing. Journal of Nonprofit \& Public Sector Marketing, 17(1-2), 1-26.

O’Reilly, N., Pegoraro, A., \& Madill, J. (n.d.). Conceptualizing the role of marketing in combating doping in elite sport. Available from: http://library.la84.org/SportsLibrary/ISOR/isor2008n.pdf

Reed, M.B., \& Aspinwall, L.G. (1998). Self-affirmation reduces biased processing of health-risk information. Motivation and Emotion, 22, 99-132.

Rothman, A.J., Bartel, R. D., Wlaschin, J., \& Salovey, P. (2006). The strategic use of gain- and loss-framed messages to promote healthy behavior: how theory can inform practice. Journal of Communication, 56 (suppl 1), S202-S220.

Sanders, A., Stogner, J., Seibert, J., \& Miller, B. L. (2014). Misperceptions of peer pill-popping: the prevalence, correlates, and effects of inaccurate assumptions about peer pharmaceutical misuse. Substance Use \& Misuse, doi: 10.3109/10826084.2014.880485.

Siabani, H., Siabani, S., Rezaei, M., Abbasi, M. R., \& Rahimi, M. A. (2008). Effect of education on performance-enhancing drug abuse by bodybuilders. Journal of Kermanshah University of Medical Sciences, 12(1). 
Sagoe, D., Molde, H, Andreassen, C., Torsheim, T, \& Pallesen, S. (2014). The global epidemiology of anabolic-androgenic steroid use: a meta-analysis and meta-regression analysis. Annals of Epidemiology, 24(5), 383-398.

Sagoe, D., Schou Andreassen, C., \& Pallesen, S. (2014). The aetiology and trajectory of anabolic-androgenic steroid use initiation: a systematic review and synthesis of qualitative research. Substance Abuse Treatment, Prevention, and Policy, 9, 27.

Saudan, C., Baume, N., Robinson, N., Avois, L., Mangin, P., \& Saugy, M. (2006). Testosterone and doping control. British Journal of Sports Medicine, 40(suppl 1), 21-24.

Schinke, S.P., Fang, L., \& Cole, K.C. (2009). Computer-delivered, parent-involvement intervention to prevent substance use among adolescent girls. Preventive Medicine, 49(5), 429-435.

Schneider, T.R., Rivers, S.E., \& Lyons, J.B. (2009). The biobehavioral model of persuasion: Generating challenge appraisals to promote health. Journal of Applied Social Psychology, 39(8), 1928-1952.

Scott, J. L., Brown, A. C., Phair, J. K., Westland, J. N., \& Schüz, B. (2013). Self-affirmation, intentions and alcohol consumption in students: a randomized exploratory trial. Alcohol and Alcoholism, 48(4), 458-463.

Skinner, H., Biscope, S., Poland, B., \& Goldberg, E. (2003). How adolescents use technology for health information: implications for health professionals from focus group studies. Journal of Medical Internet Research, 5(4), e32.

Smart, R.G., \& Fejer, D. (1974). The effects of high and low fear messages about drugs. Journal of Drug Education, 4(2), 225-235. 
Sjöqvist, F., Garle, M., \& Rane, A. (2008). Use of doping agents, particularly anabolic steroids, in sports and society. Lancet, 371(9627), 1872-1882.

Sperber, A. D., Peleg, A., Friger, M., \& Shvartzman, P. (2001). Factors associated with daily smoking among Israeli adolescents: A prospective cohort study with a 3-year follow-up. Preventive Medicine, 33(2), 73-81.

Steinberg, L. (2005). Cognitive and affective development in adolescence. Trends in Cognitive Sciences, 9(2), 69-74.

Steinberg, L. (2007). Risk-taking in adolescence: New perspectives from brain and behavioral science. Current Directions in Psychological Science, 16(2), 55-59.

Struckman-Johnson, C. (1994). Effect of persuasive appeals in AIDS PSAs and condom commercials on intentions to use condoms. Journal of Applied Social Psychology, 24(24), $2223-2244$

Terblanche-Smit, M, \& Terblanche, S. (2009). Race and Attitude formation in HIV/AIDS Fear Advertising. Journal of Business Research, 63(2), 121-125.

Tobler, N.S., Roona, M. R., Ochshorn, P., Marshall, D. G., Streke, A. V., \& Stackpole, K. M., (2000) School-based adolescent drug prevention programs: 1998 meta-analysis. Journal of Primary Prevention, 20(4), 275-336.

Van ‘t Riet, J., Cox, A. D., Cox, D., Zimet, G. D., De Bruijn, G. J., Van den Putte, B., De Vries, H., Werrij, M.Q., \& Ruiter, R. A. C. (2014). Does perceived risk influence the effects of message framing? A new investigation of a widely held notion. Psychology \& Health, 29(8), 933-949. 
van't Riet, J., Ruiter, R. A., Werrij, M. Q., Candel, M. J., \& de Vries, H. (2010). Distinct pathways to persuasion: The role of affect in message-framing effects. European Journal of Social Psychology, 40(7), 1261-1276.

Vardavas, C. I., Connolly, G., Karamanolis, K., \& Kafatos, A. (2009). Adolescents perceived effectiveness of the proposed European graphic tobacco warning labels. The European Journal of Public Health, 19(2), 212-217.

Uskul, A.K., \& Oyserman, D. (2010). When message-frame fits salient cultural-frame, messages feel more persuasive. Psychology \& Health, 25, 321-337.

Wanjek, B., Rosendahl, J., Strauss, B., \& Gabriel, H. H. (2007). Doping, drugs and drug abuse among adolescents in the State of Thuringia (Germany): prevalence, knowledge and attitudes. International Journal of Sports Medicine, 28(4), 346-353.

Witte, K., \& Allen, M. (2000). A meta-analysis of fear appeals: Implications for effective public health campaigns. Health Education and Behavior, 27(5), 591-615.

Yesalis, C.E., \& Bahrke, M.S (2000). Doping among adolescent athletes. Ballieres Clinical Endocrinology and Metabolism, 14(1), 25-35.

Yurgelun, T.D. (2007). Emotional and cognitive changes during adolescence. Current Opinions in Neurobiology, 17(2), 251-257.

Zhao, X., \& Nan, X. (2010). Influence of self-affirmation on responses to gain-versus lossframed antismoking messages. Human Communication Research, 36(4), 493-511.

Zhao, X., Nan, X., Yang, B., \& Iles, I. A. (2014). Cigarette warning labels: graphics, framing, and identity. Health Education, 114(2), 101-117.

Zimmerman, R. S., Cupp, P. K., Abadi, M., Donohew, R. L., Gray, C., Gordon, L., \& Grossl, A. B. (2014). The effects of framing and fear on ratings and impact of antimarijuana PSAs. Substance Use \& Misuse, 49(7), 824-835. 
Table 1.

Studies Included in the Review

\begin{tabular}{|c|c|c|c|c|}
\hline Authors (Year) & Title & Sample & Country & Behavior \\
\hline $\begin{array}{l}\text { Ackard \& Neumark- } \\
\text { Sztainer (2001) }\end{array}$ & $\begin{array}{l}\text { Health care information } \\
\text { sources for adolescents: } \\
\text { Age and gender differences } \\
\text { on use, concerns, and needs }\end{array}$ & $\begin{array}{l}\mathrm{N}=6728 \text { school } \\
\text { students; Yr 5-12 }\end{array}$ & United States & $\begin{array}{l}\text { Range of health } \\
\text { behavior (drugs, alc, } \\
\text { exercise, sleep, } \\
\text { pregnancy) }\end{array}$ \\
\hline $\begin{array}{l}\text { Bell, Dorsch, } \\
\text { McCreary \& Hovey } \\
\text { (2004) }\end{array}$ & $\begin{array}{l}\text { A look at nutritional } \\
\text { supplement use in } \\
\text { adolescents }\end{array}$ & $\begin{array}{l}\mathrm{N}=333 \text {; ages } 13- \\
19 \text { years }\end{array}$ & Canada & Supplement use \\
\hline $\begin{array}{l}\text { Cauberghe, De } \\
\text { Pelsmacker, Janssens } \\
\text { \& Dens (2008) }\end{array}$ & $\begin{array}{l}\text { Fear, threat and efficacy in } \\
\text { threat appeals: message } \\
\text { involvement as a key } \\
\text { mediator to message } \\
\text { acceptance. }\end{array}$ & $\mathrm{N}=170$ & Belgium & Speeding \\
\hline $\begin{array}{l}\text { Camenga, Hieftje, } \\
\text { Fiellin, Edelman, } \\
\text { Rosenthal \& Duncan } \\
\text { (2014) }\end{array}$ & $\begin{array}{l}\text { The use of message framing } \\
\text { to promote sexual risk } \\
\text { reduction in young } \\
\text { adolescents: a pilot } \\
\text { exploratory study }\end{array}$ & $\begin{array}{l}N=26 \text {; ages } 10- \\
14 \text { years }\end{array}$ & United States & Sexual behavior \\
\hline $\begin{array}{l}\text { Cho \& Salmon } \\
\text { (2006) }\end{array}$ & $\begin{array}{l}\text { Fear appeals for individuals } \\
\text { in different stages of } \\
\text { change: Intended and } \\
\text { unintended effects and } \\
\text { implication on public health } \\
\text { campaigns }\end{array}$ & $\begin{array}{l}\mathrm{N}=274 \\
\text { undergraduate } \\
\text { students; ages } \\
18-37 \text { years } \\
\text { (M=20 years) }\end{array}$ & United States & Skin cancer \\
\hline $\begin{array}{l}\text { Crano, Siegel, } \\
\text { Alvaro \& Patel } \\
(2007)\end{array}$ & $\begin{array}{l}\text { Overcoming adolescents' } \\
\text { resistance to anti-inhalant } \\
\text { appeals }\end{array}$ & $\begin{array}{l}\mathrm{N}=894 \text { sixth and } \\
\text { seventh graders; } \\
\text { ages } 11 \text { to } 13 \\
\text { years }\end{array}$ & United States & Use of inhalants \\
\hline $\begin{array}{l}\text { de Hoog, Stroebe \& } \\
\text { de Wit (2007) }\end{array}$ & $\begin{array}{l}\text { The impact of vulnerability } \\
\text { to and severity of a health } \\
\text { risk on processing and } \\
\text { acceptance of fear-arousing } \\
\text { communications: a meta- } \\
\text { analysis }\end{array}$ & $\begin{array}{l}\text { Meta-analysis; } \\
105 \text { studies; } \\
\text { N=17,919 } \\
\text { participants }\end{array}$ & Various & \\
\hline $\begin{array}{l}\text { Dunn, Eddy, Wang, } \\
\text { Nagy, Perko \& } \\
\text { Bartee (2001) }\end{array}$ & $\begin{array}{l}\text { The influence of significant } \\
\text { others on attitudes, } \\
\text { subjective norms and } \\
\text { intentions regarding dietary } \\
\text { supplement use among } \\
\text { adolescent athletes }\end{array}$ & $\begin{array}{l}\mathrm{N}=1626 ; \text { ages } \\
12-19 \text { years }\end{array}$ & United States & Supplement use \\
\hline $\begin{array}{l}\text { Freeman, Hennessy } \\
\text { \& Murzullo (2001) }\end{array}$ & $\begin{array}{l}\text { Defensive evaluation of } \\
\text { anti-smoking messages } \\
\text { among college-age } \\
\text { smokers: The role of } \\
\text { possible selves }\end{array}$ & $\begin{array}{l}\mathrm{N}=187 \text { college } \\
\text { students; ages } \\
18-22 \text { years }\end{array}$ & United States & Smoking \\
\hline $\begin{array}{l}\text { Glock, S., \& Krolak- } \\
\text { Schwerdt (2013) }\end{array}$ & $\begin{array}{l}\text { Changing outcome } \\
\text { expectancies, drinking } \\
\text { intentions, and implicit } \\
\text { attitudes toward alcohol: a } \\
\text { comparison of positive }\end{array}$ & $\begin{array}{l}\mathrm{N}=40 \text {, college } \\
\text { age students }\end{array}$ & Germany & Alcohol \\
\hline
\end{tabular}




\begin{tabular}{|c|c|c|c|c|}
\hline & $\begin{array}{l}\text { expectancy-related and } \\
\text { health-related alcohol } \\
\text { warning labels }\end{array}$ & & & \\
\hline $\begin{array}{l}\text { Goodall \& Appiah } \\
\text { (2008) }\end{array}$ & $\begin{array}{l}\text { Adolescents' perceptions of } \\
\text { Canadian cigarette package } \\
\text { warning labels: } \\
\text { investigating the effects of } \\
\text { message framing. }\end{array}$ & $\begin{array}{l}\mathrm{N}=210 \text { in high } \\
\text { school; ages } 15- \\
18 \text { years }\end{array}$ & Canada & Smoking \\
\hline $\begin{array}{l}\text { Gray, Klein, Noyce, } \\
\text { Sesselberg \& Cantrill } \\
\text { (2005) }\end{array}$ & $\begin{array}{l}\text { Health information-seeking } \\
\text { behaviour in adolescence: } \\
\text { The place of the internet. }\end{array}$ & $\begin{array}{l}\mathrm{N}=157 \text {; ages } 11- \\
19 \text { years }\end{array}$ & $\begin{array}{l}\text { United } \\
\text { Kingdom and } \\
\text { United States }\end{array}$ & $\begin{array}{l}\text { Access health } \\
\text { information }\end{array}$ \\
\hline $\begin{array}{l}\text { Hastings, Stead \& } \\
\text { Webb (2004) }\end{array}$ & $\begin{array}{l}\text { Fear appeals in social } \\
\text { marketing: strategic and } \\
\text { ethical reasons for concern. }\end{array}$ & NA & NA & $\begin{array}{l}\text { Various (safe driving, } \\
\text { sexual behaviors, } \\
\text { substance use) }\end{array}$ \\
\hline $\begin{array}{l}\text { Henley \& Donovan } \\
\text { (2003) }\end{array}$ & $\begin{array}{l}\text { Young people's response to } \\
\text { death threat appeals: do } \\
\text { they really feel immortal? }\end{array}$ & $\begin{array}{l}\mathrm{N}=995 ; \text { Smokers } \\
\text { in two age groups } \\
\text { (16-25 years and } \\
40-50 \text { years) }\end{array}$ & Australia & Smoking \\
\hline $\begin{array}{l}\text { Hevey, Pertl, } \\
\text { Thomas, Maher, } \\
\text { Craig \& Ni } \\
\text { Chuinneagain (2010) }\end{array}$ & $\begin{array}{l}\text { Body consciousness } \\
\text { moderates the effect of } \\
\text { message framing on } \\
\text { intentions to use sunscreen }\end{array}$ & $\begin{array}{l}\mathrm{N}=390 ; \mathrm{M}=20.4 \\
\text { years, } \mathrm{SD}=3.1 \\
\text { years }\end{array}$ & Ireland & $\begin{array}{l}\text { Sunbed and } \\
\text { sunscreen use / skin } \\
\text { cancer }\end{array}$ \\
\hline $\begin{array}{l}\text { Hwang, Cho, Sands } \\
\text { \& Jeong (2012) }\end{array}$ & $\begin{array}{l}\text { Effects of gain-and loss- } \\
\text { framed messages on the sun } \\
\text { safety behavior of } \\
\text { adolescents: The } \\
\text { moderating role of risk } \\
\text { perceptions. }\end{array}$ & $\begin{array}{l}\mathrm{N}=219 ; \\
\mathrm{M}=15.69, \\
\mathrm{SD}=1.33 \text { years } \\
\text { (ages } 12-18 \\
\text { years). }\end{array}$ & United States & Sun protection \\
\hline $\begin{array}{l}\text { Isaacowitz \& Choi, } \\
2012\end{array}$ & $\begin{array}{l}\text { Looking, feeling, and } \\
\text { doing: are there age } \\
\text { differences in attention, } \\
\text { mood and behavioral } \\
\text { responses to skin cancer } \\
\text { information? }\end{array}$ & $\begin{array}{l}\mathrm{N}=78 \text { (ages } 18- \\
25 \text { years); } \mathrm{N}=77 \\
\text { (ages } 60-92 \\
\text { years) }\end{array}$ & Australia & Skin cancer \\
\hline $\begin{array}{l}\text { Keller \& Lehman } \\
\text { (2008) }\end{array}$ & $\begin{array}{l}\text { Designing effective health } \\
\text { communication: a meta- } \\
\text { analysis }\end{array}$ & $\mathrm{N}=22,500$ & NA & Health behaviors \\
\hline $\begin{array}{l}\text { O’Keefe \& Jensen } \\
\text { (2008) }\end{array}$ & $\begin{array}{l}\text { Do loss-framed persuasive } \\
\text { messages engender greater } \\
\text { message processing than do } \\
\text { gain-framed messages? A } \\
\text { meta-analytic review. }\end{array}$ & NA & NA & $\begin{array}{l}\text { Health behavior } \\
\text { Disease } \\
\text { detection/prevention }\end{array}$ \\
\hline $\begin{array}{l}\text { Laure \& Binsinger } \\
(2005)\end{array}$ & $\begin{array}{l}\text { Adolescent athletes and the } \\
\text { demand and supply of } \\
\text { drugs to improve their } \\
\text { performance }\end{array}$ & $\begin{array}{l}\mathrm{N}=6,402 ; \\
\mathrm{M}=16.1 \text { years, } \\
\mathrm{SD}=2.2 \text { years }\end{array}$ & France & Dope buying and use \\
\hline Latimer et al, (2012) & $\begin{array}{l}\text { Targeted smoking cessation } \\
\text { messages for adolescents }\end{array}$ & $\begin{array}{l}\mathrm{N}=120, \mathrm{M}=16.3 \\
\text { years (phase I) } \\
\text { and } 16.8 \text { years } \\
\text { (phase II) }\end{array}$ & United States & Smoking \\
\hline $\begin{array}{l}\text { Mazanov \& Byrne } \\
(2007)\end{array}$ & $\begin{array}{l}\text { Changes in adolescent } \\
\text { smoking behaviour and } \\
\text { knowledge of health } \\
\text { consequence of smoking }\end{array}$ & $\begin{array}{l}\mathrm{N}=978 \text {; Time } 1 \\
\mathrm{M}=13.7 \text { years, } \\
\text { Time } 2 \mathrm{M}=14.5 \\
\text { years }\end{array}$ & Australia & Smoking \\
\hline $\begin{array}{l}\text { Nabi, Roskos- } \\
\text { Ewoldsen \& }\end{array}$ & $\begin{array}{l}\text { Subjective knowledge and } \\
\text { fear appeal effectiveness: }\end{array}$ & $\begin{array}{l}\mathrm{N}=263 \\
\text { undergraduate }\end{array}$ & United States & $\begin{array}{l}\text { Breast cancer women } \\
\text { for women and }\end{array}$ \\
\hline
\end{tabular}




\begin{tabular}{|c|c|c|c|c|}
\hline Carpentier (2008) & $\begin{array}{l}\text { Implications for message } \\
\text { design }\end{array}$ & $\begin{array}{l}\text { students; } M \\
=19.87 \text { years }\end{array}$ & & $\begin{array}{l}\text { testicular cancer for } \\
\text { men }\end{array}$ \\
\hline $\begin{array}{l}\text { O’Brien, Kolt, } \\
\text { Webber \& Hunter } \\
\text { (2010) }\end{array}$ & $\begin{array}{l}\text { Alcohol consumption in } \\
\text { sport: The influence of } \\
\text { sporting idols, friends and } \\
\text { normative drinking } \\
\text { practices }\end{array}$ & $\begin{array}{l}\mathrm{N}=1028 ; \mathrm{M}=20.7 \\
\text { years, } \mathrm{SD}=3.5 \\
\text { years; all }>18 \\
\text { years }\end{array}$ & Australia & Alcohol \\
\hline $\begin{array}{l}\text { Pechmann Zhao, } \\
\text { Goldberg \& Reibling } \\
\text { (2003) }\end{array}$ & $\begin{array}{l}\text { What to convey in } \\
\text { antismoking advertisements } \\
\text { for adolescents: The use of } \\
\text { protection motivation } \\
\text { theory to identify effective } \\
\text { messages themes }\end{array}$ & $\begin{array}{l}\mathrm{N}=1667 ; 46 \% \\
\text { male; } 4 \% \text { regular } \\
\text { smokers }\end{array}$ & $\begin{array}{l}\text { United States } \\
\text { and Canada }\end{array}$ & Smoking \\
\hline $\begin{array}{l}\text { Pietersma \& } \\
\text { Dijkstra, } 2011\end{array}$ & $\begin{array}{l}\text { Do behavioural health } \\
\text { intentions engender health } \\
\text { behaviour change? A study } \\
\text { on the moderating role of } \\
\text { self-affirmation on actual } \\
\text { fruit intake versus } \\
\text { vegetable intake. }\end{array}$ & $\begin{array}{l}\mathrm{N}=537 \\
\text { undergraduate } \\
\text { students }\end{array}$ & $\begin{array}{l}\text { The } \\
\text { Netherlands }\end{array}$ & $\begin{array}{l}\text { Fruit and vegetable } \\
\text { consumption }\end{array}$ \\
\hline $\begin{array}{l}\text { Rothman, Bartels, } \\
\text { Wlaschin \& Salovey } \\
\text { (2006) }\end{array}$ & $\begin{array}{l}\text { The strategic use of gain- } \\
\text { and loss-framed messages } \\
\text { to promote healthy } \\
\text { behavior: how theory can } \\
\text { inform practice. }\end{array}$ & NA & NA & $\begin{array}{l}\text { Preventive and } \\
\text { detective behaviors in } \\
\text { health care }\end{array}$ \\
\hline $\begin{array}{l}\text { Schneider, Rivers \& } \\
\text { Lyons (2009) }\end{array}$ & $\begin{array}{l}\text { The biobehavioral model of } \\
\text { persuasion: Generating } \\
\text { challenge appraisals to } \\
\text { promote health }\end{array}$ & $\begin{array}{l}\text { Two studies; } \\
\mathrm{N}=60 \\
\text { undergraduate } \\
\text { students in Study } \\
1 ; \mathrm{N}=124 \\
\text { undergraduate } \\
\text { students in Study } \\
2\end{array}$ & United States & $\begin{array}{l}\text { Fictitious contagious } \\
\text { disease }\end{array}$ \\
\hline $\begin{array}{l}\text { Scott, Brown, Phair, } \\
\text { Westland \& Schüz } \\
\text { (2013). }\end{array}$ & $\begin{array}{l}\text { Self-affirmation, intentions } \\
\text { and alcohol consumption in } \\
\text { students: a randomized } \\
\text { exploratory trial. }\end{array}$ & $\begin{array}{l}\mathrm{N}=121 \\
\text { college students }\end{array}$ & Australia & Alcohol \\
\hline $\begin{array}{l}\text { Sperber, Pelag, } \\
\text { Friger \& Shvartzman } \\
(2001)\end{array}$ & $\begin{array}{l}\text { Factors associated with } \\
\text { daily smoking among } \\
\text { Israeli adolescents: A } \\
\text { prospective cohort study } \\
\text { with a 3-year follow-up. }\end{array}$ & $\begin{array}{l}\text { N=312; Yr } 9 \\
\text { initial, Yr 11-12 } \\
\text { f/up }\end{array}$ & Israel & Smoking \\
\hline $\begin{array}{l}\text { Terblance-Smit \& } \\
\text { Terblanche (2010) }\end{array}$ & $\begin{array}{l}\text { Race and attitude formation } \\
\text { in HIV/AIDS fear } \\
\text { advertising }\end{array}$ & $\begin{array}{l}\mathrm{N}=360 \text { (ages } 5- \\
24 \text { years) }\end{array}$ & South Africa & HIV \\
\hline $\begin{array}{l}\text { Tobler, Roona, } \\
\text { Ochshorn Marshall, } \\
\text { Streke \& Stackpole } \\
\text { (2000) }\end{array}$ & $\begin{array}{l}\text { School-based adolescent } \\
\text { drug prevention programs: } \\
1998 \text { meta-analysis }\end{array}$ & $\begin{array}{l}144 \text { studies ( } 207 \\
\text { universal school- } \\
\text { based drug } \\
\text { prevention } \\
\text { programs) }\end{array}$ & Various & Drug use \\
\hline $\begin{array}{l}\text { Vardavas, Connolly, } \\
\text { Karamanolis \& } \\
\text { Kafatos (2009) }\end{array}$ & $\begin{array}{l}\text { Adolescents perceived } \\
\text { effectiveness of the } \\
\text { proposed European graphic } \\
\text { tobacco warning labels }\end{array}$ & $\begin{array}{l}\mathrm{N}=574 \text { (ages } 13- \\
18 \text { years) }\end{array}$ & Greece & Smoking \\
\hline Witte \& Allen (2000) & $\begin{array}{l}\text { A meta-analysis of fear } \\
\text { appeals: Implications for }\end{array}$ & 93 studies & Various & \\
\hline
\end{tabular}


effective public health

campaigns

Zhao \& Nan (2010)

Influence of self-

$\mathrm{N}=84$

United States

Smoking

affirmation on responses to

gain-versus loss-framed

undergraduate

student $(\mathrm{M}=$

antismoking messages

20.9 years, $\mathrm{SD}=$

2.2 years)

Zhao, Nan, Yang \&

Cigarette warning labels:

graphics, framing, and

$\mathrm{N}=132$ college

students

identity.

(smokers)

Zimmerman, Cupp, The effects of framing and

$\mathrm{N}=243$

fear on ratings and impact

undergraduate

Abadi, Donohew,

of antimarijuana PSAs

students 